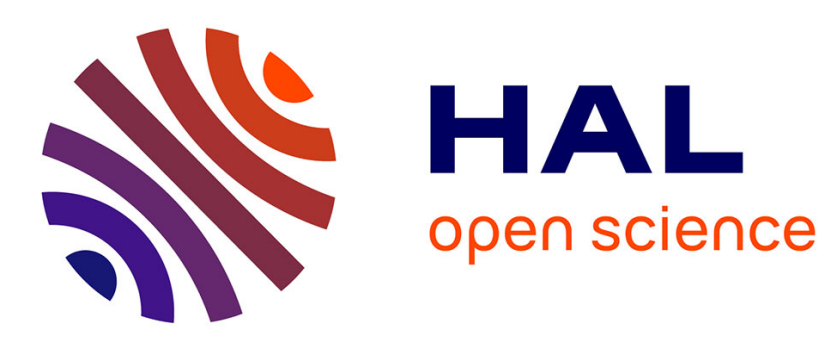

\title{
A Critical Review of Strategic Conflict Theory and Socio-political Instability Models
}

\author{
Mehrdad Vahabi
}

\section{To cite this version:}

Mehrdad Vahabi. A Critical Review of Strategic Conflict Theory and Socio-political Instability Models. Revue d'Economie Politique, 2009, 119 (6), pp.817-858. hal-00629129

\section{HAL Id: hal-00629129 \\ https://hal.science/hal-00629129}

Submitted on 5 Oct 2011

HAL is a multi-disciplinary open access archive for the deposit and dissemination of scientific research documents, whether they are published or not. The documents may come from teaching and research institutions in France or abroad, or from public or private research centers.
L'archive ouverte pluridisciplinaire HAL, est destinée au dépôt et à la diffusion de documents scientifiques de niveau recherche, publiés ou non, émanant des établissements d'enseignement et de recherche français ou étrangers, des laboratoires publics ou privés. 
A paraître dans Revue d'Economie Politique, Vol. 119, No. 6, 2009.

Title: A Critical Review of Strategic Conflict Theory and Socio-political Instability Models

\begin{abstract}
This paper provides a critical general overview of two strands of recent vast economic literature on social conflicts, namely strategic conflict theory and socio-political instability models. The first strand can be traced back to Haavelmo (1954) and has been further developed in a variety of ways by game theoretical models of rational conflict (Boulding, 1962; Schelling, 1963, Hirshleifer, 2001). Their goal is to understand threat power. A second version of conflict theory has been developed by the founders of the Public Choice School (Olson 1965, 1982; Tullock 1974, 1980; Stringham, 2005, 2007) in order to tackle genuine political violence.
\end{abstract}

The main finding of this paper is that both strands of recent economic literature have not yet come to grips with social conflicts. The application of standard microeconomic assumptions to the field of "social conflicts" has resulted in reducing conflicts either to "rational conflicts"- a threat of conflict without any real clash - or "real self-interested private conflicts". In other words, economic theory has considered social protesters either as looters or lunatics, but never as a group of people struggling for a common cause.

Keywords: Strategic Conflict Theory, Socio-political instability models, Coase theorem, Appropriative activity, Social Conflicts

\title{
JEL Classification: D74, H41, H56
}

Titre : Un survol critique de la littérature sur la théorie du conflit stratégique et les modèles d'instabilité sociopolitique

\section{Résumé}

Cet article fournit un survol critique de deux branches récentes de la vaste littérature économique portant sur les conflits sociaux, à savoir la théorie du conflit stratégique et les modèles d'instabilité sociopolitique. La première branche peut être retracée à Haavelmo (1954), et a été formalisée depuis par de nombreux modèles du conflit rationnel s'inspirant de la théorie des jeux (Boulding, 1962; Schelling, 1963, Hirshleifer, 2001). Leur objectif consiste à comprendre le pouvoir de menace. Une seconde branche de la théorie des conflits a été développée par les fondateurs de l'école du choix public (Olson 1965, 1982; Tullock 1974, 1980; Stringham, 2005, 2007) qui essaie de traiter de la violence politique authentique.

Notre survol critique démontre que l'application des postulats standards de la microéconomie dans le domaine des conflits sociaux conduit à réduire ces conflits soit en "conflits rationnels », c'est-à-dire en une menace de conflits sans aucune confrontation réelle, soit en «conflits réels pour les intérêts prives ». En d'autres termes, cette littérature décrit les contestataires sociaux comme des pilleurs ou des ignorants et irrationnels, mais jamais comme un groupe social se battant pour une cause commune.

Mots clés : Théorie du conflit stratégique, modèles d'instabilité sociopolitique, le théorème de Coase, activité appropriative, conflits sociaux

\section{JEL Classification: D74, H41, H56}




\title{
A Critical Review of Strategic Conflict Theory and Socio- political Instability Models
}

\begin{abstract}
Mehrdad VAHABI ${ }^{1}$

\section{Introduction}

Neoclassical economic theory does not deny conflictual or antagonistic interests caused by scarcity. But as Varoufakis and Young (1990) aptly point out, this general opposition or antagonism must be distinguished from conflictual activity involving the use of resources (including time) to resolve competition between contending interests. In other words, antagonistic interests need not necessarily develop into open confrontation.
\end{abstract}

The critical assumption of neoclassical economics postulates that conflicts of interest in the economy are resolved in contracts that are either voluntarily observed or are enforceable at no cost to the exchanging parties. Abba Lerner (1972, p. 259) described the role of conflict in the Walrasian model in the following terms: "With or without a fight, there is a settlement or compromise in which the rights are defined. Those who benefit from the activity gain the approval of those who object by giving them something to get them to agree. What I want particularly to stress is that the solution is essentially the transformation of the conflict from a political problem to an economic transaction. An economic transaction is a solved political problem."

Exchanges may be solved political problems where contracts are comprehensive and enforceable at no cost to the exchanging parties. By 'solved political problem', Lerner means the absence of power relationships. Contractual incompleteness provides a logical foundation for conflictual activity: "Allowing for the possibility of conflict, which amounts to recognizing the possibility that property rights are not perfectly and costlessly enforced, represents a significant departure from the traditional paradigm of economics." (Garfinkel and Skaperdas, 2007, p. 650).

According to Bowles and Gintis $(1988,1990)$, if some aspect of the object of exchange is too complex or difficult to monitor, to the degree that comprehensive contracts are not feasible or are feasible only by a third party, then the exchange is contested. Contested exchange entails conflicts that cannot be resolved through voluntary contracts. In this case, we are confronted with social conflict. Social conflict entails unsolved political problems.

\footnotetext{
${ }^{1}$ The author is Associate Professor at the University of Paris 8, Saint Denis (Vincennes). His email address is: mehrdad.vahabi@wanadoo.fr. This paper is dedicated to my sister Mandana Vahabi (loti ba marefat) who could never be sufficiently thanked for all her support. I would like to thank two anonymous referees for their valuable comments. All my thanks also go to Sylvie Lupton and Ilyess El karouni for their inspiring and insightful remarks. Obviously, all the remaining errors are mine.
} 
Social conflict is a struggle waged by a group of people for a common cause. There are two main characteristics for social conflicts. First, unlike market-type conflicts, which are carried out within a voluntary exchange framework, social conflicts involve coercive power and domination. Second, social conflicts assume people struggling for "common interests" and not only for private individual interests (Vahabi, 2009b). As Lerner correctly reminds, the Walrasian model precludes such type of conflict.

Despite the exclusion of social conflicts from the field of economics, economic theory accepted a particular type of conflict. Since any competitive activity implies a certain type of conflict of interest among agents, the neoclassical school has largely developed theories of conflict which may be called "system neutral" or "pro-systemic" (Gupta, 1990) according to which conflicts remain within the rules of the market economy. The competitive, oligopolistic and monopolistic strategies have been analysed by Cournot, Stackelberg, Edgeworth, Richardson, Von Neumann, Morgenstern, and others (see Schmidt, 1993) on the basis of some fundamental behavioural assumptions such as rationality and maximization. But what about other types of conflictual activities involving coercive power?

Economic literature has identified the utilitarian dimension of coercive power as a means of appropriation since Pareto ([1927] 1971, p. 341): "The efforts of men are utilized in two different ways: they are directed to the production or transformation of economic goods, or else to the appropriation of goods produced by others". Despite this early recognition of the appropriation theme, it occupied a marginal place in our discipline till recently.

Treating appropriation as a basic form of economic activity requires a theoretical framework in which predatory activity could have a positive though decreasing marginal utility. Rational agents could be involved in such type of activity as long as it does not bear negative value. The goal is to explain appropriation according to rational conflict, which excludes real destruction. Rational conflict refers to threat power and can be defined as a bargaining procedure without any real clash or conflict between the parties, which are both partners and adversaries. Examples of strategic conflict theory include negotiations about nuclear power, commercial negotiations within the GATT or WTO, and negotiations between institutionalized trade unions and employers' organizations on wage and work conditions.

Haavelmo (1954) pioneered a canonical general equilibrium model of the allocation of resources among appropriative and productive activities with no fictitious auctioneer. Over the last four decades, the model has been interpreted in a variety of ways using game theory models of rational conflict (Boulding, 1962; Schelling, 1963) within a partial equilibrium framework particularly along Cournot (Hirshleifer, 1991a,b) and Stackelberg equilibrium ${ }^{2}$. This body of work is coined as "strategic conflict theory" by Schelling (1963). Their common theoretical contention is that appropriative activities are rationally influenced by the opportunity cost of

\footnotetext{
${ }^{2}$ The appropriation issue has been introduced into modern economic literature in the areas of international conflict, alliances and revolution (Sandler and Hartley, 1995), crime (Becker, 1968), rent-seeking (Tullock, 1967) and the coercive dimensions of the state (McGuire and Olson, 1996). Another strand of work endeavours to integrate appropriation into the core of neoclassical microeconomics (Bush, 1972; Bush and Mayer, 1974; Buchanan, 1975; Hirshleifer, 1991, 1995; Skaperdas, 1992; Grossman and Kim, 1995, 1996a,b). For a recent detailed survey of different strands of conflict theory, see Garfinkel and Skaperdas, 2007.
} 
foregone production "in the shadow of conflict" (Anderton, Anderton, and Carter, 1999). Is social conflict integrated in this type of modeling?

The first section of the present paper will tackle this problem. Our critical review of various models of strategic conflict theory shows that they do not integrate social conflicts since they do not capture the logic of coercive power. They consider markets to be a ubiquitous and invariable form of economic organization, and implicitly assume that any economy can be translated into market terms. This line of thought makes it necessary to stretch the content of the concepts of "voluntary exchange" and "mutual gain from trade" to embrace "exchange of threats". In this context, a robbery, for example, is defined as an "implicit contract" between the robbed and the robber: the latter preserves the life of the former in return for a certain amount of money. Similarly, social protestors such as striking employees are depicted as potential looters or lunatics.

To put differently, strategic conflict models are built upon the extension of the Coasian theorem (1960) to coercive power. This explains why rational conflicts are neutral. Neutrality of conflicts connotes a lack of need for real clashing or conflictual action, so a redistribution of wealth or reallocation of resources may occur despite conflictual interests among agents (Vahabi, 2009b). In a sense, in standard economics, conflict is treated like money: it is neutral with regard to economic performance and disappears in equilibrium.

A second version of conflict theory has been developed by the founders of the Public Choice School (Stringham, 2005, 2007), notably by Olson $(1965,1982)$ and Tullock $(1974,1980)$ in order to tackle genuine political violence. They have studied not only threat power but also real conflictual situations such as revolutions, wars, terrorist activities, etc. Their goal is to extend the standard microeconomic assumptions to other fields of social sciences such as politics. They thus endeavour to incorporate real conflicts in economic analysis and provide a theoretical framework for a New Political Economy (Vahabi, 2009a).

Real conflicts are not neutral, and have a clear impact on economic performance, since they come within the scope of rent-seeking activities and involve not only deadweight losses but also pure destruction ${ }^{4}$. New Political Economy has produced a vast literature on political and appropriative conflicts under the name of "socio-political instability models" (Drazen, 2000). Three types of modelling of socio-political instability can be distinguished, namely the rational expectation model of political violence, predation models, and common property models. The last two variants of political instability models have many commonalities and similarities with strategic conflict models notably with regard to the use of game theory and the extension of Coase theorem (1960) to coercive power. Nonetheless, they belong to a different research program which gives the pride of place to real conflicts with a clearly political dimension.

The second section of the paper will provide a critical review of this more recent version of socio-political instability models. We disentangle different shades and types of modelling within

\footnotetext{
${ }^{3}$ Similarly, the market exchange relationship is extended to include all forms of social interactions, including ones based on explicit coercion such as slavery, feudalism, or predatory allocation of resources (North, 1977).

${ }^{4}$ While "deadweight losses" are analyzed in economics of conflict, pure destruction is often ignored. The primacy of pure destruction is particularly stressed in economics of destructive power (see Vahabi, 2010).
} 
the nebulous field of New Political Economy and question whether social conflict is integrated in this line of thinking. Our contention is that although this literature integrates real conflicts into economic theory, it does not grapple social conflict. The reason resides in the fact that real conflicts are theorised on the assumption of a strictly self-motivated private interest. From this perspective, social protestors are considered as actual looters, but not as people struggling for a common cause. In our critical assessment, the main shortcoming of this approach is the use of individual cost-benefit analysis that cannot capture the logic of "transformation of costs into benefits" (Hirschman, 1970) in social conflicts.

In this paper, I will thus provide a critical overview of these two strands of recent economic literature on social conflicts ${ }^{5}$. Section one will introduce strategic conflict theory and underline its limits. Section two will be entirely devoted to different variants of socio-political instability models. This strand of economic modelling will be compared with the strategic conflict models and its shortcomings will be highlighted. A short conclusion will follow.

\section{Strategic conflict theory}

From a methodological point of view, "strategic conflict theory" is based upon rationality assumption and maximizing behaviour of agents: "It is faithful to our definition of "strategy": it takes conflict for granted, but also assumes common interest between the adversaries; it assumes a "rational" value-maximizing mode of behaviour; and it focuses on the fact that each participant's "best" choice of action depends on what he expects the other to do, and that "strategic behaviour" is concerned with influencing another's choice by working on his expectation of how one's own behaviour is related to his." (Schelling, 1963, p. 15). The theory tries to capture the "threat" or "potential" versus actual destruction in case of a limited (but not total) war. This amounts to saying that the principal subject of the theory is "deterrence" and not real war or social conflicts questioning the whole social system.

Deterrence was of course a favourite topic of the cold war during the sixties, but it was far from total war, civil war, or other destructive phenomena on a large scale. "(T)hough "strategy of conflict" sounds cold-blooded, the theory is not concerned with the efficient application of violence or anything of the sort; it is not essentially a theory of aggression or of resistance or of war. Threats of war, yes, or threats of anything else; but it is the employment of threats, or of threats and promises, or more generally of the conditioning of one's own behaviour on the behaviour of others, that the theory is about." (Schelling, op.cit., p. 15). Moreover, the "deterrence" is regarded as if it consists of bargaining between rational, maximizing commercial partners. In fact, in this approach the conflict coexists with mutual dependence, and the adversaries are also partners. Schelling calls it "the theory of precarious partnership or the theory of incomplete antagonism".

\section{I.1 Rational conflicts as a process of bargaining}

Conflict theory uses game theory to explicate the strategy of adversaries as players in a game which is not the zero-sum-game, since there is no unique winner or loser. It also explores other types of games: variable-sum-games instead of constant-sum-games. "On the strategy of pure

\footnotetext{
${ }^{5}$ For a recent detailed survey of the literature see also Vahabi, 2004, Chapter 2 and Garfinkel and Skaperdas, 2007.
} 
conflict - the zero-sum-games - game theory has yielded important insight and advice. But on the strategy of action where conflict is mixed with mutual dependence - the nonzero-sum games involved in wars and threats of war, strikes, negotiations, criminal deterrence, class war, race war, price war, and blackmail...traditional game theory has not yielded comparable insight or advice." (Schelling, 1963, p. 83). The problem with this type of game theory is that it is based on the same fundamental assumptions that the zero-sum game is grounded on, namely rationality and maximizing behaviour. Three major shortcomings can be raised with regard to the methodology of strategic conflict theory.

First, it supposes that the agents are rational in the sense that "the participants coolly and "rationally" calculate their advantages according to a consistent value system" (Schelling, 1963, p. 16). In social conflicts such as wars, revolutions, or even serious and protracted strikes (such as that of English miners against Thatcher's government), the distinction between costs and benefits is blurred, since every individual participant behaves as if s/he represents all the others. In such circumstances, the social identity of every individual or her/his behaviour as a dynasty overshadows his/her individual interests. Dying for the "cause" is not only a "cost", but is considered to be a "benefit". In other words, as Hirschman justly remarks: "it is in the nature of the "public good" or the "public happiness" that striving for it cannot be neatly separated from possessing it. This is so because striving for the public happiness will often be felt not so much as a cost, but as the closest available substitute for it." (Hirschman, 1970, p. 9).

Second, individuals participating in a social movement do not have constant choices. They learn about social realities through their participation and understand about their own social choice. For example, at the beginning of the social unrest in 1978 in Iran, many people did not know about the role of the Shah in supporting the corruption and oppression by high officials and the royal family. They believed that the king was good, but his associates were corrupt. The same thing is true with what the majority of Iranian citizens thought about Khomeini and the Islamic Republic on the morrow of the Iranian February revolution in 1979. Lenin used to say that during revolutionary periods, people learn each day more than what they have learnt in ten years. This amounts to saying that during revolutionary periods, as well as during any important collective action, individual's social preferences change very rapidly. The rationality hypothesis requires given preferences which are known in advance and regrouped according to the transitivity principle. Hence this rapid change of preferences is not consistent with the rationality hypothesis.

Third, in game theory, the costs/benefits and strategies of agents are supposed to be known to the agents. It does not mean that game theory ignores uncertainty. It incorporates the parametrical type of uncertainty, where the probability of occurrence of any event and the corresponding strategy, costs and benefits associated with such an event are known beforehand. Put differently, game theory only excludes radical uncertainty and assumes the predictability of events. While such an assumption may hold true in generic or routine situations, in case of social conflicts, the "rationality" assumption lacks any serious meaning of rationality. In fact, how can the occurrence of an event be predicted during social turmoil where everything is in the process of change? As Proudhon rightly observed, the predictability of an event is an oxymoron: "The fecundity of the unexpected far exceeds the stateman's prudence." (Cited in Arendt, 1970, p. 7).

The singleness of every major social conflict excludes any predictability or "rationality" assumption. That explains why Richard Goodwin (1968) in his review of Thomas Schelling's 
Arms and Influence (1966) severely criticised this book for giving credence to the dangerous idea that we can "predict events" and have "control over their flow". This critique is even more powerful if we remember that in case of variable-sum-games, in contrast to constant-sum-games, each actor's decision influences the other actor's decision, and thus the unpredictability concerns not only the occurrence of events but also the way each player interprets unprecedented events and anticipates the possible interpretation of the other player! Schelling, himself, notes the difficulty: "There is no way to build a model for the interaction of two or more decision units, with the behaviour and expectations of those decision units being derived by purely formal deduction. An analyst can deduce the decisions of a single rational mind if he knows the criteria that govern the decisions; but he cannot infer by purely formal analysis what can pass between two centres of consciousness. It takes at least two people to test it." (1963, p. 163).

Now, if the analyst does not know the criteria that govern the decisions of an agent, since the agent's own choice is changing and if the analyst cannot clearly determine the boundaries of costs and benefits in the agent's calculation, and if the analyst cannot know the objective utility function of the agent since s/he behaves as if s/he is a collective agent, and if the analyst cannot attach any probability to the occurrence of events, then how many people would it take to test our game theoretical model?

My objection to the "strategy conflict theory" does not limit itself to these methodological considerations. The major shortcoming of this strand of conflict theory is that the exchange of goods and services is stretched to include the "exchange of threats" and the market model is assumed to deal with the power relationship. It does not consider the idiosyncratic logic of coercive power as one of the specific characteristics of genuine social conflicts. As Schelling highlights, the theory is not concerned with the efficient application of violence, aggression, or war. The conflict is viewed as a process of strategic bargaining. This particular conception of "conflict" is directly inspired by the way commercial negotiations and competitive market strategies are carried out.

Coase's theorem (1960) can thus be applied to coercive power: individuals have an incentive to bargain for the redistribution of wealth under coercion as long as they maximize their joint gains and transaction costs are not too great. Exchange of threats does not involve the actual use of coercion or destruction; it only requires threat power, or the theoretical possibility of coercion.

Undoubtedly, threats involve a general difficulty. Sen (1983, p. 17) convincingly argued that "The person who threatens to harm the other if the bargaining should fail does it at no direct advantage to himself (otherwise it won't be a 'threat' but something he may do anyway, and will be thus reflected in the fall-back position). While it is plausible to try to get bargaining advantage out of a threat during the process of bargaining, once the bargaining has failed, the threatener has no obvious interest in carrying out the threat. But that recognition on the part of the threatened person would call into question the credibility of the threat itself."

This is a general predicament in Nash equilibrium theory within the context of extensive games. Nevertheless, threats do actually take place. Since competitive equilibrium theory (e.g., subgame perfection) does not allow for real threats, it is preferable to apply the Nash equilibrium theory in specific contexts. 
The extension of the application of Coasian theorem to conflict depicts it as a bargaining process between conflictual parties who are simultaneously partners and adversaries (Vahabi, 2009b). The problem with this type of extension is that even at an abstract level, "market exchange" (voluntary or involuntary) cannot be equated with an "exchange of threats". To distinguish between these two cases, it suffices to compare them with a state of autarky. A voluntary or involuntary market exchange is preferable to autarky, but autarky is preferable to the exchange of threats.

To sum up, the "strategy conflict theory" cannot overcome the pitfall of the mainstream economics with regard to social conflicts, since its fundamental assumptions exclude the idiosyncratic logic of coercive power.

\section{I.2 Strategic bargaining models with destructive power}

A recent economic study on "strategic bargaining with destructive power" corroborates the "strategy conflict theory". This literature shares the fundamental assumptions regarding rationality and maximizing behaviour with the conflict theory. It builds upon the non-zero-sum game theoretical models. However, the objective of this literature is not to study the "deterrence" or other strategic considerations of the cold war period. It tries to capture the role of workers' destructive power as part of "strategic bargaining models". Its particular fields of application are strikes and suspension of talks during the labour contract negotiations (for example between the Canadian Auto workers and General Motors in 1998), commercial negotiations during the different rounds of the GATT or the World Trade Organization (WTO), and negotiations between trade unions and firms. This literature is concerned not only with efficient strikes, but also with the "threat" of strike. Accordingly, one of the main problems examined in this literature is the credibility of threats or the commitment to put a threat into effect.

In these game theoretical models, destructive power refers either to the power of bargainers to destroy part of the surplus or to their ability to inflict a cost on their opponent, without actually damaging the object bargained over. The first form of destructive power is analyzed in Dasgupta and Maskin (1989), Manzini (1997, 1999), and Busch et al. (1998). The second form of destructive power is dealt with in Avery and Zemsky (1994) where the authors call such kind of activity "money burning". This literature has tackled both destructive power and commitment to use it. In Dasgupta and Maskin (1989) destructive power is modelled in a way that both bargainers (employers and employees) have destructive power and can actually destroy part of the surplus to be shared. Nevertheless, in their model, commitment by bargainers to use such a power plays no role. In Busch et al. (1998), they discuss a bargaining model in which one of the players has the power to destroy any proportion of the surplus during disagreement periods.

Like Dasgupta and Maskin (1989), the authors show that destructive power increases the player's bargaining power even in the absence of commitment to use it. Manzini (1999) studies a simple two-player alternating offers bargaining model in which one of the players is allowed to destroy part of the surplus bargained over. Commitment plays no role in this model either. Obviously, commitment can arise in a number of real life circumstances, for example, a union can commit itself to a predetermined length of strikes in order to increase its bargaining power. Such a kind of situation is modelled by Holden (1994). Muthoo (1992) examines a situation where one of the bargainers representing a group of people is committed to a proposal previously adopted by his 
representees and in case he wants to break his commitment, he should bear the cost. Manzini (1997) models the joint effect of destructive power and commitment to use it in an alternating offers bargaining model in which one of the players can commit to damage the surplus that they are bargaining over.

As our review indicates, in all these models, destructive power is studied in the framework of a negotiating procedure with hyper-rational, and maximizing agents. All other uses of destructive process involving a "total war" or actual destruction are excluded. In fact, for this literature a "total war" is just a zero-sum game with rational and maximizing agents, whereas a "partial war" should be examined through more interesting and complicated non-zero sum games. The fundamental problem with this kind of modelling is that social conflicts are limited to bargaining procedures that remain within the ubiquitous market rules. Since Coase's theorem (1960) is assumed to apply to coercive power, all movements which debilitate the social and economic order are excluded.

\section{Destructive power and political violence}

This section will first introduce "socio-political instability" models and highlight their differences with "strategic conflict theory". Then, a general classification of "political instability" models based on the two aspects of political violence, namely motivational and instrumental will be discussed. Finally, we will examine successively each type of model and endeavour to show the insufficiency of this literature to grasp the institutional aspect of social conflicts reducing them to sheer looting.

\subsection{Socio-political instability models and conflict theory}

During the 1980s and 1990s, a neoclassical theory of political violence was developed that can be regarded as a strand of public choice theory with particular application for political violence. In economics, this theory is known as the new political economy of "socio-political instability" (Drazen, 2000, pp. 500-513), and in insurance theory, it is named "political risks" (HabibDeloncle, 1998). There is no unique definition of "political instability". According to Alesina and Perotti (1994, p. 355), there are two ways to define this concept. The first is to construct an index of socio-political instability (SPI) that summarizes several indicators of more or less violent forms of political protest and social violence. The SPI approach begins with a list of variables that identify events such as riots, political demonstrations against the government, and assassinations. For instance, Perotti (1996) uses the following index of socio-political instability:

$\mathrm{SPI}=1.60$ ASSASS + 2.33 DEATH + 7.29 SCOUP + 6. 86 UCOUP - 5.23 DEM

where ASSASS $=$ number of political assassinations per million population per year; DEATH $=$ violent deaths per million population per year; SCOUP = number of successful coups per year; UCOUP = number of unsuccessful coups per year; and DEM = a dummy variable which is 1 for countries with an average value of Jodice and Taylor's (1988) democracy index of greater than 0.5 , and 0 (zero) otherwise. The weights are chosen by the method of principal components. 
The second (Alesina and Perotti, 1994) focuses on executive turnovers, namely on the frequency of government collapses. These two methods are used by economists to test empirically the impact of political violence on economic growth.

In the insurance literature, a third measure is defined which is directly linked to the security of property. This measure is a subjective indicator of "country risk" produced by specialized firms, particularly by English, American, and French private insurance companies. The "country risk" includes several indicators such as sovereign default risk, risk of nationalization or expropriation, inconvertibility or non transferability of currencies, protection of expatriate staff, measures related to the "rule of law" and the enforceability of contracts, and the level of bureaucracy and corruption. Since the end of the seventies, private insurance companies such as Lloyds have accepted to insure foreign branches of multinational corporations against "political risks" in countries where such risks are considered to be high. The insurance contract is confidential and it covers risks due to unpredictable events such as revolutions, political or governmental changes, wars and civil wars. Since 1996, the global market of "political risk" has radically increased. In 1998 , the total capacity of this market in case of non-enforceability of contracts amounted to 100 million dollars and the insurance sum in case of expropriation of capital goods exceeded 700 million dollars (Habib-Deloncle, 1998, p. 1216). This third measure of "country risk" has been used by Knack and Keefer (1995), Mauro (1995), and Svensson (1998) among others.

The burgeoning literature on "political instability" is related to practical needs regarding the costs and benefits of political violence and the security of property rights. In contrast to "strategic conflict theory", this literature deals with real or genuine political violence. It cannot be criticized for ignoring real social conflicts and it gives the impression that the neoclassical theory has finally resumed the classical tradition of political economy. Nevertheless, a closer comparison of "strategic conflict theory" with "political instability" literature displays the theoretical consistency of the former and the lack of solid theoretical assumptions of the latter. In fact, "strategic conflict theory" had no claim to represent realistic conflicts; it was mainly concerned with "rational conflict" or "threat" as part of a bargaining procedure between parties who were supposed to be both partners and adversaries.

The adoption of "rationality" and "maximizing" assumptions by conflict theorists was incompatible with realistic conflicts, but these assumptions were entirely consistent with a normative theory of rational conflict. In "political instability" literature, the object of modelling is not a rational but realistic conflict; however the fundamental assumptions of "rationality" and "maximization" are maintained. In this case, the theoretical inconsistency between real conflict and expected rationality assumptions is dismissed by postulating an individual maximizing behaviour for a rioter or a revolutionary militant. Put differently, the theorists of "political instability" usually rule out particular political, psychological, or social motivations for political violence and assume pure individual economic motivation for participants in political violence in order to investigate the utilitarian dimension of political violence. Their method in social science can be named "economic imperialism". And it is not so hard to show the incongruousness of their assumptions with the motivations involved in real social conflicts.

\footnotetext{
${ }^{6}$ Lazear defines "economic imperialism" as follows: "Economists, almost without exception, make constrained maximization the basic building block of any theory...the theoretical revisions almost never drop the assumption that individuals are maximizing something, even if the something is unorthodox..we do not model behaviour as being
} 
In fact, Mancur Olson's theory of collective action proclaimed the impossibility of collective action for large groups due to free-rider problem just before the explosion of important social movements at the end of the sixties in the Western countries. If any individual can benefit from collective action without sharing the costs of actively participating in it, then there can be no revolution made by masses. There can only be revolutions made by "small conspiratorial groups": "It is natural then that the "Marxian" revolutions that have taken place have been brought about by small conspiratorial elites that took advantage of weak governments during periods of social disorganization." (Olson, [1965]1980, p. 106).

Despite the inconsistency between Olson's theory and the reality of massive social movements, his theory was widely praised, and it is now considered to be one of the pioneer contributions of public choice theory. Hirschman's explanation of this paradoxical phenomenon is thought provoking: "It seems to me paradoxically conceivable that the success of Olson's book owes something to its having been contradicted by the subsequently evolving events. Once the latter had safely run their course, the many people who found them deeply upsetting could go back to the Logic of Collective Action and find in it good and reassuring reasons why those collective actions of the sixties should never have happened in the first place, were perhaps less real than they seemed, and would be most unlikely ever to recur. Thus the book did not suffer from being contradicted by subsequent events; rather, it gained by actively contradicting them and became a great success among those who found these events intolerable and totally aberrant. In this manner, false prophecy can be the foundation stone of fame and reputation in the social sciences." (Hirschman, 1982, pp. 78-79). Hirschman is, of course, not a partisan of "economic imperialism". He stresses in Exit, Voice, and Loyalty that he has been guilty, not of imperialist ambition or designs, but rather the opposite, namely "the desire to convince economists of the importance and usefulness, for the analysis of economic phenomena, of an essentially political concept such as voice." (1974, pp. 7-8; see also Hirschman, 1981, pp. 267-68). This theoretical polemic between Hirschman and Olson touches one of the most controversial aspects of conflict theory, namely the motivational underpinnings of political violence.

\subsection{Motivational and instrumental aspects of political violence}

The concept of political violence should be clearly distinguished from the notion of conflict in "conflict theory". Sociologists and economists have both stressed this distinction. Schelling differentiates between "rational" and "non-rational" conflict, Coser (1956, p. 59) demarcates "realistic" from "non-realistic" conflict, and Galtung (1965, p. 349) pinpoints the difference between "destructive behaviour" and "conflict behaviour". The distinction is not linguistic or descriptive, but analytical. The essence of the distinction is "between actions instrumental in securing the values sought and actions destructive for their own sake. The analytic usefulness of the distinction is not in question; what is questionable is attempting to account for political violence using theoretical approaches that assume that only the instrumental manifestations of violence are relevant or subject to analysis." (Gurr, 1970, p. 45; the first two emphases are mine).

determined by forces beyond the control of individuals. Most sociologists, by contrast, argue that understanding the constraints is more important than understanding the behaviour that results from optimization, given the constraints." (2000, p. 100). 
Conflict theorists, such as Coser and Galtung, acknowledge this double aspect of conflictual behaviour. However, economists are mainly concerned with the instrumentalist aspect of the behaviour, since it can be easily fitted in a utilitarian approach consistent with rationality and maximizing assumptions. Political scientists (Huntington, 1968; Gurr, 1970) have taken issue with the question of the ubiquity of costs/benefits motivation in analyzing political violence. They stress the interest of analyzing political violence for its own sake (i.e. motivational aspect of political violence) as well as for its tactical or instrumental value (i.e. instrumental aspect of political violence).

Incorporating both aspects of political violence in a general theory of violence, Gurr (1970) gives equal weight to "non-rational origins and manifestations" of conflictual behaviour. He particularly invokes frustration and fear as psychological drives of violence, and develops a theory of "relative deprivation" to explain the potential for collective and political violence. By "relative deprivation", he means the discrepancy that people perceive between their value expectations and their value capabilities (Gurr, 1970, p. 37). For example, a discrepancy between what people actually possess in terms of political and economic goods and what they think is justly theirs, can be defined as their "relative deprivation" (RD). Inspired by the Freudian theory of sexual urge and death wish, Gurr considers men to have a capacity but not a need for aggression. The need for aggression is related to RD. Hence the basic frustration-aggression proposition is that the greater the frustration, the greater the quantity of aggression against the source of frustration.

This postulate provides the motivational base for an initial proposition about political violence: the greater the intensity of deprivation, the greater the magnitude of violence. Gurr focuses on three forms of political violence, namely turmoil, conspiracy, and internal war. The theory of RD tries to explicate all "relatively spontaneous, unorganized political violence with substantial popular participation" (riots), as well as "highly organized political violence with limited participation" (conspiracy), and "highly organized political violence with widespread popular participation" (internal war) (op.cit., p. 11). Thus, political violence includes all subversive activities and is not limited to conflicts within a political or social order. In this sense, it is part and parcel of destructive power, although destructive power also embraces non-violent forms of social conflicts (Vahabi, 2004).

RD theory pertains to individual psychological motivations of participants in political violence and it usually overrides the peculiarities of social conflict itself. For instance, Gurr's main conclusion is that " $(\mathrm{T})$ here are violent societies, that we know something about how they originate and perpetuate themselves, and that the discontents that precede violence in them are probably more amenable to change than the attitudes that justify it." (1970, p. 192). But are there really "violent societies"? Taking Vietnam as an example, can we say that the protracted national liberation war of the Vietnamese people was due to their "frustration-anger" or RD motives?

It seems to me that the Vietnamese resort to violence can be better understood if we take on board three social facts: 1) the use of violence by the United States of America against the Vietnamese people; 2) the intensity of the struggle and its protracted character; and 3) the international situation that could not prevent the United States to launch the war against Vietnam. Neither can Vietnamese society be considered as a "violent society", nor can their resort to 
violence be explained by their "frustration-anger". Frustration-anger or RD do not necessarily lead to political violence. Many other factors, notably social and institutional ones, are crucial for the emergence of political violence. Despite these critical remarks, Gurr's contribution has the particular merit of inquiring into the nature and the genesis of political violence. His theory of political violence influenced certain economists who analyze "political instability" on the basis of psychological assumptions about human behaviour.

Gupta (1990) clearly follows Gurr's theory of RD. Although Gupta's main concern is the instrumental aspect of political violence, he does not ignore the motivational aspect. Consequently, he develops a rational expectation model of political violence without assuming a maximizing behaviour. Nonetheless, the majority of economic models on "political instability" completely ignore the motivational or causal aspects of political violence, and focus on its economic effects or on its instrumental aspect. According to Hirshleifer (1991a, p. 130), modelling of conflict began with Fredrick Lanchester ([1916] 1956). The importance of Lanchester's simple model in analyzing "fighting efficiency" parameters of two conflicting forces and their relative attrition rates notwithstanding, "political stability models" are inspired by Haavelmo's long-neglected contribution on economic evolution. In this book, the author provided a canonical general equilibrium model of the allocation of resources among appropriative (or "grabbing" according to Haavelmo's terminology) and productive activities in order to develop a theory of international or inter-regional trade (Haavelmo, 1954, pp. 91-98).

In this model, Haavelmo acknowledges rationality postulate (1954, p. 84), but he does not adopt the maximizing assumption. He uses a set of "conjectural response functions" for describing the possible reaction of one region towards the other regions with regard to "productive, grabbing, and protection" activities (1954, pp. 94-98). Summarizing the results of his study regarding the inter-regional activities compared to a centralized or a completely decentralized economy, the author pinpoints that "There is absolutely no reason to assume that there should be any automatic tendency towards an 'optimal' policy with regard to world output in the same sense as in a centrally directed economic unit. The decisive factors in shaping the historical interrelations between the regions may well have been conjectures regarding countermeasures, coupled with hopes for gains in a free-for-all atomistic market." (1954, p. 98).

Contrary to the conflict theory or the political instability models, Haavelmo's early model of "grabbing" activities is not based upon the maximizing assumption. Nevertheless, a number of theorists have reinvented his formalization of this problem and added the maximizing hypothesis in order to develop a general equilibrium model of appropriative or predatory activity. These models are constructed on rationality and maximizing assumptions and they can be grouped in three strands of formal modelling.

The first strand develops a rational expectation model of conflictual behaviour which takes into consideration insurrections, riots, and other forms of political violence. However, in dealing with political collective violence, two different approaches can be distinguished. The first approach assumes that successful insurrections mainly produce social benefits from which active insurgents cannot exclude non partisans. These social-benefit theories stress the importance of such factors as "ideology", class identification, and anomie in overcoming the free-rider problem associated with non excludability (Roemer, 1985, 1988; Gupta, 1990). The second approach emphasizes private returns of insurrection and considers social consequences as complementary 
(Tullock, 1974; Usher and Engineer, 1987; Popkin, 1988; Taylor; 1988; Tong; 1988; Grossman, 1991, Macculloch, 2005, Collier and Hoeffler, 2007) ${ }^{7}$.

The second strand follows Grossman and Kim's (1995, 1996a) model of predation which describes the allocation of resources to productive, predatory, or defensive activities. Grossman and Kim (1996b) apply the predation model to growth. Following the same line of modelling, Anderson and Marcouiller (2002, 2005), Skaperdas and Syropoulos (2002) and Stefandis (2007) examine the relationships between property rights institutions, appropriation and openness to international trade.

The third strand, known as "common property models", pertains to situations where the property rights are threatened to be expropriated and redistributed, and examines the implications of such insecurity. In common property models, society is described as a sum of powerful groups which are either in a cooperative or in a conflictual relationship. Social conflict is modelled as the appropriative activity of a group for its own self-interest instead of cooperating with other groups. This "rent-seeking" activity can follow two different types of strategies.

The first type of strategy can be dubbed "simple strategy" and it consists of appropriating an optimal constant rate of the common property for one's own interest. The second type of strategy is more complicated, since it alludes to a variable rate of appropriation of the common property by rent-seekers. This rate depends on the amount of wealth and is called "wealth dependent strategies". Thus the third strand of socio-political instability models or "common property models" can be divided into two sub-group models: 1) The "common property models with constant appropriation" (Drazen, 2000, pp. 502-507). Tornell and Velasco, 1992; Lane and Tornell, 1996, 1999; Tornell, 1997 have developed such kind of models; and 2) the "common property models with wealth-dependent appropriation" (Drazen, 2000, pp. 507-513). Benhabib and Rustichini (1996) and Long and Soger (2004) have modelled this version of common property models. The following table summarizes theories on political violence.

\footnotetext{
${ }^{7}$ In his survey of "models of domestic political conflict", Lichbach (1992), distinguishes two different branches of formal modeling in conflict theory: i) international conflict; ii) domestic political conflict (DPC). He claims that while formal modelers of international conflict think of themselves as working within a field, formal modelers of DPC do not cite each other and do not constitute a real field. The main result of his survey is that "there are only two modeling traditions in DPC studies that are cumulative: stochastic modeling and expected utility modeling. Stochastic modelers have consistently depicted outbreaks of DPC as random. Expected utility modelers have consistently depicted rational rebels as choosing not to rebel. These traditions are not only internally cumulative; they also turn out to be externally consistent." (1992, p. 342). The interest of an exhaustive literature review on this topic notwithstanding, Lichbach's survey suffers from some important shortcomings. For instance, he classifies Hirschman (1970) and Gurr (1970) under the general title of "Rational choice models", and more specifically cites Hirschman's model (1970) as a "deterministic utility maximization” model (1992, p. 354) and Gurr's model (1970) as a "spatial theory" $(1992,357)$. Gupta (1990) is also classified as "expected utility model" (1992, p. 354), whereas Gupta's model denies the maximizing assumption. Moreover, in Lichbach's long list of references, Haavelmo (1954) and Schelling's work are not cited.
} 
Table 1. A taxonomy of real and rational conflict theories

\begin{tabular}{|c|c|c|c|}
\hline $\begin{array}{c}\text { Type of } \\
\text { conflict }\end{array}$ & $\begin{array}{l}\text { Potential conflict } \\
\text { or threat power }\end{array}$ & $\begin{array}{l}\text { Real conflict for its } \\
\text { own sake } \\
\text { (motivational aspect) }\end{array}$ & $\begin{array}{l}\text { Real conflict as a means } \\
\text { (instrumental aspect) }\end{array}$ \\
\hline $\begin{array}{l}\text { Rationality } \\
\text { assumption }\end{array}$ & Haavelmo (1954) & & $\begin{array}{l}\text { Frustration-anger, } \\
\text { political } \\
\text { theory, and Ideologility's } \\
\text { effect, or general } \\
\text { equilibrium models of } \\
\text { insurrection with social } \\
\text { benefits for insurgents } \\
\text { Gupta, 1990; Roemer, } \\
1985,1988 \text {. }\end{array}$ \\
\hline $\begin{array}{l}\text { Rationality, } \\
\text { maximizing } \\
\text { assumptions }\end{array}$ & $\begin{array}{l}\text { Conflict theory } \\
\text { Schelling (1963, } \\
1966)\end{array}$ & & $\begin{array}{l}\text { I. General equilibrium } \\
\text { models of insurrection } \\
\text { with private benefits for } \\
\text { insurgents (Olson, 1965; } \\
\text { Tullock, 1974; Popkin, } \\
\text { 1988; Taylor, 1988; } \\
\text { Tong, 1988; Grossman, } \\
\text { 1991, Collier and } \\
\text { Hoeffler, 2007; Blattman } \\
\text { and Miguel, 2009). } \\
\text { II. Predation model } \\
\text { (Grossman and Kim } \\
\text { 1995, 1996a,b; Anderson } \\
\text { and Marcouiller, 2002, } \\
\text { 2005) } \\
\text { III. Common property } \\
\text { models: 1) Common } \\
\text { property models with } \\
\text { constant appropriation } \\
\text { (Lane and Tornell, 1999); } \\
\text { 2) Common property } \\
\text { models with wealth- } \\
\text { dependent appropriation } \\
\text { (Benhabib and Rustichini, } \\
\text { 1996; Tornell, 1997; } \\
\text { Long and Sorger, 2004) }\end{array}$ \\
\hline $\begin{array}{l}\text { Non rational, } \\
\text { psychological } \\
\text { individual } \\
\text { motivations }\end{array}$ & & $\begin{array}{l}\text { Relative deprivation } \\
\text { theory } \\
\text { Gurr, } 1970\end{array}$ & $\begin{array}{l}\text { Relative deprivation } \\
\text { theory } \\
\text { Gurr, } 1970\end{array}$ \\
\hline
\end{tabular}

Apart from these theoretical models, there exists a vast literature on econometric tests which are used to examine empirical evidences with regard to the relationship between political instability 
and growth ${ }^{8}$. Although the pioneer studies of Hibbs (1973) show that political instability has no effect on growth, several papers find a significant negative relation between socio-political instability and economic growth (Drazen, 2000, p. 523). Due to political instability and insecurity regarding property rights, the level of investment decreases and subsequently, economic growth declines. Hence two questions should be answered. First, what is the cause of political instability that leads to sharp reductions in economic growth? Second, in what kind of political regime can political risks lead to expropriation?

Rodrik (1997) tackles these two questions and provides some very general answers. He considers the "depth of pre-existing social cleavages in a society, along the lines of wealth, ethnic identity, geographical region" as the basis of "latent" social conflicts that can bring about political instability. In such a society, if the domestic institutions of conflict management have weak conflict resolution, then a serious political crisis can turn into a situation of expropriation. Rodrik's analysis addresses motivational factors that underpin social conflicts. Conversely, some authors argue that where a rebellion is financially and military feasible it will occur regardless of the motivation of rebels. "Feasibility rather than motivation is decisive for the risk of rebellion" (Collier, Hoeffler and Rohner, 2009, p. 23). Econometric tests strongly support the significance of feasibility hypothesis. Blattman and Miguel (2009) also insist on the importance of econometric tests regarding the causes of civil war. However, they argue that micro level analysis and data are needed to truly decipher war's causes, and understand the recruitment, organization, and conduct of armed groups. Finally, the consequences of civil war are particularly discussed in Collier and Hoeffler (2007).

\subsection{Political instability models}

In this section, I discuss three types of modelling of socio-political instability, namely the rational expectation model of political violence, predation models, and common property models. In each case, we will only substantiate canonical models which have been the source of subsequent discussions and refinements. Other models are only quoted in relation to these canonical models. Our critical survey will single out the importance of motivational and ideological factors in rational expectation models. For this type of modelling, the maximization assumption is not required. However, predation models and common property models insist on maximization assumption and privately interested individuals. The utilitarian dimension of violence is particularly emphasized in predation models to explain insurrections and other violent forms of destructive activity. The inconsistencies of this type of modelling with historical evidences will be documented. Finally, "organized social groups" and "voracity effect" will be identified as specific features of common property models.

\subsubsection{Rational expectation models of political violence}

Rational expectation models of political violence can be grouped in two different types. The first type comprises of social-benefit theories which underline the importance of such factors as ideology. John Roemer's (1985) contribution to the analysis of revolution as a two-person game

\footnotetext{
${ }^{8}$ For two recent detailed surveys on empirical evidences, see Collier and Hoeffler (2007), and Blattman and Miguel (2009).
} 
is a good example. He believes that free riding in revolutionary coalitions is indeed overcome by a change in agents' preferences from those of the prisoner's dilemma to those of the assurance game. By "assurance game", I mean a game in which each agent derives more utility from cooperating than from defecting, given the other one cooperates. According to Roemer, "Revolutionary participation simply cannot be explained by side payments or coercion, factors appealed to in the pure self-interest model (Olson)." $(1985,90)$.

He also assumes that Lenin and the Tsar are both non-ideological in the sense that each behaves in a disinterested manner to achieve his goal. Lenin maximizes the probability of revolution, and the Tsar minimizes it. Nevertheless, each of them finds it optimal to behave in what might be interpreted by an outside observer as ideological'. Roemer $(1985$, p. 90; 1988, p. 234) "endows Lenin with a charisma which enables him to convince people to behave cooperatively" and to participate massively in the revolution against the Tsar, although the layers of the population who do not have sufficient political courage to rise against the Tsar will also benefit from Lenin's progressive program if the revolution achieves victory. It is noteworthy that contrary to Roemer, Mancur Olson ([1965] 1980, p. 106) and Gordon Tullock (1974, p. 45) claim that Lenin never tried to overcome the free-rider problem in the Russian revolution, since his organizational project to build the Russian Social-democratic party, as defined in What is to be done (1902), was based on the idea of "professional revolutionaries". In other words, Lenin was relying on "a committed, self-sacrificing, and disciplined minority, rather than on the common interests of the mass of the proletariat." (Olson, ([1965] 1980, p. 106).

It is true that rational, value-maximizing thinking about the uses of violence is more characteristic of leaders than followers. But revolutions are not made by leaders; they are made by large masses. There exist many examples to illustrate the uselessness of conspiracies to provoke revolutions. Janos (1964, p. 81) notes that Louis Auguste Blanqui called out the people of Paris thirteen times in the mid- and late-nineteenth century, but never successfully. In 1870, "the workers of Paris stood by apathetically while Blanqui and his storming party were arrested after an unsuccessful appeal to the masses, yet only three weeks later the same masses spontaneously rose to overthrow the government of Louis Napoleon." (Janos, 1964, p. 84). Leaders are more prone to "rational, value-maximizing" calculation about the use of violence, but they are also less immune to errors and "irrationality" as Blanqui's example illustrates!

Gupta (1990) provides another example of the social-benefits theory of collective rebellion. In this type of modelling, the maximizing assumption is denied. Other theorists emphasize the fact that social consequences of insurrection do not preclude having private returns (Usher and Engineer, 1987; Popkin, 1988; Taylor, 1988; Tong; 1988, Macculloch, 2005). A salient example of this type of approach is Grossman's general equilibrium model of insurrection. In this model, the peasant families, as the ruled class, respond to the ruler's policies by allocating their labour time to production, soldiering, or participation in an insurrection "with the objective of maximizing their expected income. In a successful insurrection, the insurgents take as booty all of the revenue of the ruler and his clientele." (Grossman, 1991, p. 912; the emphasis is mine).

\footnotetext{
${ }^{9}$ In fact, Roemer tries to rationalize what might otherwise appear as "ideological" behaviour of Lenin and the Tsar. He models "ideology" as "a (self-imposed) limitation by the agent on the set of feasible strategies he might choose in an attempt to achieve a goal." (1985, p. 86).
} 
Put differently, insurgents behave like looters, since their main objective is to enrich themselves. Grossman even defines insurrection in such a way that the distinction between "revolutionaries" and "bandits" becomes blurred: "The analysis that follows defines insurrection generally to include any forceful action against the established system of property rights and taxation. This definition does not distinguish between rebels or revolutionaries... and bandits or pirates...In actual cases, this distinction can be blurred (see, for example, the discussion of pre-modern China in James Tong [1988])" (1991, p. 913). Perhaps the distinction between revolutionaries and bandits is blurred in "pre-modern China", 10 , but it is hard to sully this distinction in the American Revolution for independence (1776), the French Revolution (1789), the Russian Revolution (1917), the recent Iranian Revolution (1979), or in all other major revolutions. This privatebenefits type of modelling builds upon rationality and maximizing assumptions and it has been further developed by Predation models. In this section, we examine social-benefits theory, particularly the work of Gupta (1990), since he explicitly advocates a rational expectation model of collective rebellion without postulating a maximizing behaviour.

Borrowing from Gurr's (1970) work, Gupta (1990) develops a rational expectation model of political violence. He acknowledges the importance of individual psychological impulsions, particularly that of frustration or relative deprivation, in explaining aggressive behaviour. However, he argues that relative deprivation cannot be the sole explanation of aggression and notes that the broad definition of "frustration" fails to specify the kind of aggressive act in which an individual is likely to engage (Gupta, 1990, p. 84). He distinguishes five acts of collective rebellion: political demonstrations, riots, political strikes, armed or guerrilla attacks, and assassinations (op.cit., p. 104). According to Gupta, all these forms of violence are "antisystemic" in the sense that they are not "system neutral" conflicts or conflicts within the rules of the market (op.cit., pp. 15, 19). He pinpoints the role of such conflicts in institutional change. Frustration does not always lead to aggressive behaviour. The step between frustration and aggression is not direct and is complicated by choice of action (with varying degrees of satisfaction or benefit), fear of retaliation, and ideology.

In fact, "a rational actor will weigh his choice of action against its possible consequences in light of all these factors." (op.cit., p. 85). So a model explaining participatory behaviour in political actions must be based on a costs/benefits analysis. Moreover, the frustration that one feels as an individual may not always be translated into political action. Instead "it may lead to criminal activities, or an individual may engage in psychotic behaviour ranging from homicidal to suicidal. But when will frustration lead to political violence?" Gupta argues that "for the feeling of frustration to translate into a collective action, it must relate to the collective identity" (op.cit., p. 85). This collective identity implies an ideological orientation. Hence, Gupta suggests that Gurr's frustration theory be amended by a costs/benefits analysis and that ideology or "collective interests" be included in the utility function of agents.

\footnotetext{
${ }^{10}$ Not only in China but also in many other countries, social banditry is not limited to "plundering", "looting" or pirate activities. In fact, social banditry is rural, not urban. The peasant societies in which it occurs know rich and poor, powerful and weak, rulers and ruled, but remain "profoundly and tenaciously traditional, and pre-capitalist in structure. The bandit is a pre-political phenomenon, and his strength is in inverse proportion to that of organized agrarian revolutionism and socialism or communism." (Hobsbawm, 1963, p. 23, underlined by me). Hence, it is a little incongruous to compare "pre-modern" social banditry in China with modern political revolutions in order to sully the distinction between "revolutionaries" and "pirates". Nevertheless, even in pre-modern social banditry, the importance of Robin Hoodism and the ethical aspiration for justice should not be ignored (Hobsbawm, 1963).
} 
The only point which distinguishes Gupta's analysis from Gurr's theory of violence is Gupta's standpoint on costs/benefits analysis. Gupta is mainly concerned with the instrumental or utilitarian aspect of political violence, although he does not neglect the value of political violence for its own sake, especially in defining the individual's participatory motivation. This explains why he proposes a rational expectation model of political violence without the maximizing assumption.

Undoubtedly, there is a tactical use of violence, since it can be used for value enhancement or for "looting". The most direct utilitarian use of violence is to seize a desired good, as rioters do when they pillage warehouses and as conspirators do in a coup d'état. Other tactical uses of violence are anti-government riots and strikes which are sometimes designed to induce rulers to change undesirable policies. A common indirect use of violence is to demonstrate symbolically the demands of those resorting to violence and the intensity with which they vindicate these demands. In other words, it displays the capacity of protestors to disrupt the socio-political order if their demands are not met. Nevertheless, there exists a great difference between looters and social protestors in resorting to violence. In the former case, the "rational" calculation of looting is based on a net separation of costs and benefits, whereas in the case of political protests, there is usually no such net separation between costs and benefits. As Hirschman (1982, pp. 85-86) notes, the neat distinction between costs and benefits of action in the public interest vanishes, since striving, which should be entered on the cost side, turns out to be part of the benefit.

Furthermore, in every revolutionary movement, "revolutionary idealism" (Plekhanov, [1894] 1974) or "revolutionary utopianism" (Gurr, 1970, p. 216) has played a great role. What is "revolutionary idealism"? It is the illusion of having the ability to end all the inequality, oppression and misery in one stroke and to create a harmonious fraternal society just on the morrow of revolution. This wave of optimism during the revolutionary period reflects the relative ignorance of revolutionaries about the real potential of revolution and it is usually followed by a wave of pessimism after the end of the revolutionary period. If one adopts a consistent utilitarian outlook, one may ask whether this "revolutionary idealism" enhances the interests of revolution. My answer to this question is affirmative. I argue that a utilitarian approach is not necessarily a good bedfellow of rationality.

One good example is the illusion of French Enlighteners about whom Plekhanov writes very lucidly: "Turn the pages of Mably's Doutes, proposés aux philosophes économistes or Morelli's Code de la nature and you will see that inasmuch as these writers' views differed from those held by the vast majority of the Enlighteners in respect of the conditions for human welfare, and inasmuch as they dreamt of the abolition of private property, they, in the first place, came into glaring contradictions with the most essential and vital needs of the nation in their times, and, in the second place, vaguely aware of that, they themselves considered their aspirations absolutely impracticable. Consequently, I ask you again: wherein lay the ignorance of the Enlighteners? Did it consist in the fact that, while being aware of the social needs of their times and correctly indicating how they could be met (through the abolition of the old privileges, and the like), they attributed an extremely exaggerated significance to the methods needed, i.e., the significance of a road towards universal happiness? This was not yet crass ignorance; from the practical point of view, it should even be recognized as quite useful, since the more the Enlighteners believed in the 
universal significance of the reforms they demanded, the more energetically they had to work for their achievement." ([1897] 1976, p. 240, the last paragraph is emphasized by me).

Revolutionary idealism or utopianism is the source of extraordinary efforts which make possible the overthrow of entrenched regimes. Another salient example of the efficiency of this type of utopianism is the creation of one of the most powerful, courageous, efficient and yet cheapest army of Europe under Napoleon Bonaparte. This revolutionary army was the most formidable child of the Jacobinic Republic. From a "levée en masse" of revolutionary citizens it soon turned into a force of professional fighters, for there were no call-ups between 1793 and 1798, and those who had no taste or talent for soldiering deserted massively. It therefore retained the characteristics of the Revolution and acquired those of the vested interest; the typical Bonapartist mixture.

Regarding the origin of this army during the Terror period, Hobsbawm writes: "(B)y March 1794 an army three times as large as before was run at half the cost of March 1793, and the value of the French currency...was kept approximately stable, in marked contrast to both past and future...The Republic of the Year II had coped with worse crises and with fewer resources." (1962, p. 68). How could they reduce the costs of the army so drastically and so rapidly? The answer can be found in the reports of Savant, one of the soldiers of this army, who is quoted by Hobsbawm: "Do you know what kind of government (was victorious)? ...A government of the Convention. A government of passionate Jacobins in red bonnets, wearing rough woollen cloth, wooden shoes, who lived on simple bread and bad beer and went to sleep on mattresses laid on the floor of their meeting-halls, when they were too tired to wake and deliberate further. That is the kind of men who saved France." (1962, p. 68).

Personal sacrifices are the source of this high and rapid reduction of costs. Such a kind of economies of resources is done in all revolutions without any exception and it naturally remains a puzzle for the Olsonian's theory of the free-rider behaviour! Moreover, the interesting point is that the revolutionary masses usually make such great sacrifices because of their "revolutionary utopianism", namely their relative ignorance, and not because of their "rationality". But does it mean that "revolutionary utopianism" is devoid of all historical rationality? Revolutionary utopianism has no ex ante rationality, but it has an ex post rationality, since no revolution can achieve its goals without great sacrifices by masses who are not concerned about the costs and benefits of their actions. If revolution is a particular form of collective action to change the existing socio-political rules, then revolutionary utopianism is a necessary condition for changing existing rules with the least costs. In this sense, revolutionary utopianism is ex post rational.

\subsubsection{Predation models}

A second strand of socio-political instability modelling is derived from the "predation model" (Grossman and Kim, 1996a). This model is developed in the general theoretical framework of conflictual behaviour as a rent-seeking activity. The fundamental postulates of the economic theory of conflict can be summarized in two points: "1. Optimization: Each competitor chooses a preferred balance of productive effort and conflictual effort. 2. Equilibrium: On the social level, the separate optimizing decisions interact to determine levels of production and the extent of fighting activity, together with the distribution of production among the claimants." (Hirshleifer, 2001, p. 17). 
As a general principle, resources can be used not only for production but also for appropriative purposes such as theft and warfare. "Individuals and groups can either produce and thus create wealth or seize the wealth created by others." (Garfinkel and Skaperdas, 1996, p. 1). Predation models are parts of an emerging literature on conflict and appropriation (Skogh and Stuart, 1982; Hirshleifer, 1987, 1991a, b, 1995; Findlay, 1996; Skaperdas, 1992; Garfinkel and Skaperdas, 1996; Skaperdas and Syropoulos, 1996). This type of modelling is also used to examine the effect of insecure property and its accompanying enforcement costs on the efficiency of exchange (Skaperdas and Syropoulos, 2002). In the same vein, Anderson and Marcouiller (2002, 2005), and Stefandis (2007) study the relationships between property rights institutions and appropriation in case of autarky and openness to international trade.

In this literature, the use of force, or the threat of using force, is a primary determinant of aggregate outcomes; appropriative activities include the use of swords, bombs, or guns. Individuals and pressure groups are supposed to be involved in appropriating goods from others. The wealth of a richer agent gives a poor agent an incentive to prey on the richer agent and, perhaps, even to be a pure predator. Jack Hirshleifer (1991b) provides an interesting example alluding to what he calls "the paradox of power". This paradox can be defined in following terms: if the relative endowment of an agent is sufficiently small, then that agent allocates all its resources to predatory activities. Grossman and Kim (1995) have developed a predation model with two agents in which purely aggressive equilibrium is excluded and no agent is entirely specialized in predatory activities. Grossman and Kim (1996a) relax this assumption to allow for the possibility that a poor agent might choose to specialize in predatory activity ${ }^{11}$.

In this model, there exist two types of agents: 1) a predetermined potential predator, who allocates his/her resources to producing consumption goods and "offensive weapons" in order to appropriate the prey's property; 2) a predetermined potential prey, who allocates his/her

\footnotetext{
${ }^{11}$ Grossman and Kim (1996a) cite the Vikings and the Mongols as historical evidences of the type of specialisation in pure predatory activity. But the Vikings and the Mongols were not poor people. The navigation power of the Vikings and the pastoral way of life among the Mongols may be better reasons to explicate their specialization in predatory activity. Another good example is the Spartans who prospered while at war but began to decline once they reached a position of supremacy. They did not understand what being at peace meant and never attached any importance to any other kind of activity than training for war. Aristotle writes: "Public finance is another thing that is badly managed by the Spartans. They are obliged to undertake large wars, but there is never any money in the treasury." (Politics, p. 90). The Spartans were not poor, but they were bad in managing their public finance, whereas they were great warriors. In other words, they could more easily deal with a war economy than with a peace economy; this is also true for the Vikings and the Mongols. In my opinion, specialization in predatory activity does not depend necessarily on "poverty" or "wealth", but on the particular allocation of resources on different types of entrepreneurial talents (productive or predatory ones). Contrary to the contention of Hirshleifer (1991b) and Grossman and Kim (1996a), historical evidence does not always confirm that "poor agents" choose to specialize in predatory activity. In fact, many historical examples illustrate the fact that rich agents choose to specialize in predatory activity. Skaperdas and Syropoulos's (1996) model as well as Kennedy's book (1989) highlight the close relationship between commerce and war, or between trade and colonialist policies. Aristotle argues that equality of wealth will not put an end to stealing and he also notes that rich people can specialize in predatory activity. He considers this behaviour as "major crime": "As for major crimes, men commit them when their aims are extravagant, not just to provide themselves with necessities. Who ever heard of a man making himself a tyrant in order to keep warm? For the same reason, the magnitude of the crime, there is more credit in slaying a tyrant than slaying a thief. So we may conclude that the typical characteristics of Phaleas's constitution would be a protection only against minor crimes." (Politics, p. 75).
} 
resources to produce consumption goods and "defensive fortifications". The model abstracts from all specific institutional setups and concentrates on a general equilibrium with predatory activities. The authors investigate three types of equilibria: 1) a non-aggressive equilibrium, where a predator devotes no efforts on predation; 2) a pure predation equilibrium, where a predator devotes no efforts on production; 3) a part-time predation equilibrium, where a predator divides his/her efforts between productive and predatory activities. The modelling is based on a game theoretical framework. The prey has to move first and s/he disposes of an initial endowment $\left(\mathrm{e}^{\mathrm{d}}\right)$. This initial endowment is the constraint under which the prey has to divide its capital between "defensive fortifications" $\left(\mathrm{x}^{\mathrm{d}}\right)$ and production of consumption goods $\left(\mathrm{k}^{\mathrm{d}}\right)$ :

$e^{d}=x^{d}+k^{d}$

The predator moves next and s/he divides his/her initial endowment $\left(\mathrm{e}^{\mathrm{o}}\right)$ between "offensive weapons" $\left(\mathrm{x}^{\mathrm{o}}\right)$ and the production of consumption goods $\left(\mathrm{k}^{\mathrm{o}}\right)$ :

$\mathrm{e}^{\mathrm{o}}=\mathrm{x}^{\mathrm{o}}+\mathrm{k}^{\mathrm{o}}$

The production is a linear function with a coefficient $(\alpha)$. In the case of predation $\left(x^{0}>0\right)$, the prey preserves a fraction $(\theta)$ of her/his endowment. This fraction depends on the relative amount of resources devoted to "offensive weapons" and "defensive fortifications": $\theta=\Omega\left(x^{0} / x^{d}\right)$, with $\Omega^{\prime}<0$. Final wealth is $\mathrm{w}^{\mathrm{j}}(\mathrm{j}=\mathrm{d}, \mathrm{o})$, and since predation destroys resources ${ }^{12}$, the final wealth may be less than the initial endowments:

$\mathrm{w}^{\mathrm{d}}+\mathrm{w}^{\mathrm{o}}<\mathrm{e}^{\mathrm{d}}+\mathrm{e}^{\mathrm{o}}$

An agent's objective is to maximize the sum of consumption goods and final wealth, denoted $\delta^{\mathrm{j}}=$ $\alpha \mathrm{k}^{\mathrm{j}}+\mathrm{w}^{\mathrm{j}}$. The model's equilibria are Nash equilibria and they are based on optimal choices of $\mathrm{x}^{\mathrm{o}}$ and $x^{d}$. The various equilibria depend on relative initial endowments $\left(\lambda=e^{d} / e^{o}\right)$, and the effectiveness of predation compared to defensive activities $(\mu)$. Three possibilities can be distinguished.

If $\lambda$ and $\mu$ are both small (i.e. if both agents are poor and the predatory activity is not so effective) then there will be a non-aggressive equilibrium. If $\lambda$ is large, whereas $\mu$ is neither too large nor too small (i.e. if the predator is poorer than the prey), then it will be profitable for the predator to allocate its resources entirely to the predatory activity. In this case, we will have pure predation equilibrium. If $\mu$ is too small, then we will be once again in a non-aggressive equilibrium even if

\footnotetext{
${ }^{12}$ Grossman and Kim (1995, pp. 1279-1280; 1996a, p. 60; 1996b, p. 335) allow for the possibility that predation can be destructive. By this, they mean that the predator gains less from predation than the prey loses. This destruction or damage due to fighting can be called "collateral damage". Grossman and Kim measure this "destructiveness of predation" by a parameter $0 \leq \beta \leq 1$. For example, perhaps the predator's gain is subject to deterioration during shipment, or the predator's gain needs to be processed to be usable. Specifically, although the prey dynasty loses the fraction $1-\mathrm{P}_{\mathrm{t}}$ of its gross production, the predator dynasty gains only the fraction $(1-\beta)\left(1-\mathrm{P}_{\mathrm{t}}\right)$ of the prey's gross production. Hence, "predatory activity" should not be confused with "destructive activity" in general. Furthermore, it should be noted that because the destructiveness of predation deters predation, the smaller the cost of appropriative activities, the more destructive predation would be. In a non-military context, Becker's (1983) analysis of pressure groups competition shows how incidental damage to the economy ("deadweight loss") tends to limit the extent of conflict.
} 
$\lambda$ is large, since the ineffectiveness of offensive weapons will not allow the potential predator to allocate its resources to predatory activity. If $\mu$ is too large (i.e. if the offensive weapons are extremely effective), then the potential predator does not need to devote all its effort to predatory activity and can carry out both productive and destructive activity. In this last case, we will have part-time predation equilibrium (Grossman and Kim, 1996a, pp. 65-70).

Grossman and Kim (1996b) have extended this model to a growing dynamic economy. Inherited wealth can be devoted to one of three activities: 1) consumption of production goods; 2) accumulation of productive capital; and 3) production of "offensive weapons" or "defensive fortifications". Growth depends on the amount of accumulation of productive capita, whereas the redistribution of wealth from prey to predator depends on the effectiveness of predatory activities. The destruction of the wealth would be an outcome of devoting all resources to defensive and offensive actions. Hence, the growth of an economy can be directly affected by predatory or protective activities. Grossman and Kim (1996b) describe protective activities as those that guarantee the security of property rights, and thence develop a theory of property rights in a growth model. They conclude that the property rights would be secure if the potential prey devotes sufficient resources to protective activities so that the predator would be dissuaded to engage in offensive activities. Moreover, they argue that since the security of property rights is not costless, it may sometimes be more profitable not to guarantee it fully and tolerate a certain level of predation. In fact, the authors show that certain societies which tolerate predation sometimes grow more quickly than those that always give priority to the full security of property rights.

There is another interesting case relevant to predatory activity which Aristotle notes in Politics. Nonetheless, the afore-mentioned models do not discuss it. A country may choose a slow rate of growth in order to dissuade other countries from invading it. Aristotle writes: "A nation's wealth is part of its strength; for it is essential that there should be resources sufficient not merely for its internal needs but also to meet external dangers. For this purpose the total amount of property ought not to be so large that more powerful neighbours will covet it, and the owners be unable to repel the invasion; on the other hand, it must not be so small that they cannot finance a war against an equal or similar foe. Phaleas of course fixed no limit and there is no denying that surplus wealth is very useful. But a limit there should be, and perhaps the best way of stating it would be to say that the total wealth should not be so great as to make it profitable for a stronger power to go to war attracted by its great size, but only such as might be wanted in a war not motivated by the attraction of huge wealth." (Politics, p. 76) ${ }^{13}$.

In this case, the slow rate of growth is not caused by the use of resources in protective activity (as it is argued in Grossman and Kim's model), but is a deliberate choice of a country. In Grossman and Kim's model, this case cannot be discussed independently of the rate of the effectiveness of

\footnotetext{
${ }^{13}$ In the following paragraph, Aristotle examines the costs and benefits of surrounding a city in terms of "offensive weapons" and "defensive fortifications": "For example, when Autophradates was about to lay siege to Atarneus, its ruler Eubulus asked him to consider how long it would take him to complete the capture of the city, and then to count the cost of a war of that duration. 'For', he added, 'I am willing now to abandon Atarneus in return for a sum of money very much less than that.' These words of Eubulus caused Autopharadates to think again and to abandon the siege." (Politics, p. 76). Undoubtedly, economic calculation is a major aspect of any organized war between two nations, tribes, or states. Aristotle also acknowledges the importance of the effectiveness of "offensive weapons" compared to "defensive fortifications" $(\mu)$ in waging the war.
} 
offensive weapons, since there are two independent variables, namely $\lambda=e^{d} / e^{o}$ (the relative initial endowments) and $\mu$ (the effectiveness of offensive weapons). In other words, even if $\lambda$ is small, the type of equilibrium depends on the value of $\mu$. This result is based upon the assumption that $\lambda$ and $\mu$ are independent. Now, if we assume that $\mu$ is a function of $\lambda, \mu=F(\lambda)$, and that they are positively related to each other, then

$\mu=a \lambda+b$, where $a, b$ are the parameters and $a>0$.

This assumption amounts to claiming that greater (lesser) differences in initial endowments (or economic inequalities) provoke greater (lesser) specialization in destructive activities. This assumption is compatible with many real situations and corresponds to what Hirshleifer (1991b) coins as high "decisiveness of conflictual effort". When decisiveness is low, the rich focus on producing a larger social pie of income even though this means that the poor will acquire an improved share. However, when conflictual superiority entails a considerable difference in achieved income, for instance when the battle is "winner takes all", the rich avoid allowing the poor to win the contest over distributive shares. Accordingly, high decisiveness is more advantageous to the better-endowed parties, since they can invest more heavily in "fighting technology" and be in a better position with regard to contest power.

In fact, the rent-seeking predation models can be used to justify an optimal allocation of resources to police departments in order to reduce criminal activity. However, there exists a certain level of poverty (and hence a certain critical level of $\lambda$ ) for which any protective measure cannot dissuade "predatory" activities of poor people against property rights. In other words, I suggest that there is a critical value for $\lambda$ (a poverty trap) for which the predatory activity becomes inelastic with regard to the variation of $\mu$. This critical level is not discussed in predatory models.

Our principal objection to predatory models is that they do not provide any analysis about the origin and nature of predatory actions. In fact, predatory actions can include criminal, revolutionary, and warlike activities. But these models entirely ignore the distinctions between these various types of predatory actions and assume that such an action is equivalent to plundering (rent-seeking) and necessarily derives from pure economic calculation with regard to maximizing the utility function of individual agents (or dynasties).

Moreover, these models do not inquire into the specific properties of destructive activity and do not provide an internal explanation for violence and destruction. As noted earlier, "predatory activity" is different from "destructive activity", even though predation involves destruction, and the "destructiveness of predation" is taken into account in Grossman and Kim $(1995,1996 \mathrm{a}, \mathrm{b})$ by a parameter $(\beta)$. However, given complete information and the absence of stochastic factors, these models do not involve violence and destruction. We should not forget that in these general equilibrium models, agents are assumed to be hyper-rational. If they are aware of all states of nature (there is no radical uncertainty) and can rationally calculate their costs and benefits in different types of aggressive and non aggressive equilibria, then they can anticipate the necessary conditions to avoid real destruction and violence. 
Grossman and Kim acknowledge that "Another possibility would be that predation involves violence and destruction. But given complete information and the absence of stochastic factors, this model does not provide an internal explanation for violence and destruction." (Grossman and Kim, 1995, p. 1279; 1996a, p. 60; 1996b, p. 347). In other words, Predation models as well as general equilibrium models of collective rebellions do not treat real destruction or violence, since they are based on rational expectation, complete information, and the predictability of all relevant states of nature. Hence, these models maintain the basic assumption of the Public Choice approach: rational people will usually not rebel!

Brito and Intriligator (1985) address the question of whether appropriative conflict is resolved with or without violence and destruction, and they stress the importance of incomplete information as a cause of violence. They distinguish between the threatened use of force in attempting to reallocate resources, which they call "conflict", and the actual use of weapons, which they name "war". Drawing upon models of bargaining with asymmetric information, they introduce two equilibrium concepts, namely separating equilibrium and pooling equilibrium. In the first type of equilibrium, the uninformed agent attempts to induce the other party (informed one) to reveal the pertinent characteristic. In the pooling equilibrium, the uninformed agent does not attempt to induce the other party (informed one) to reveal the pertinent characteristic. The authors show that if two conflicting countries are both fully informed about the parameters of the problem, there will be no redistribution by actual war. Rather, there will be a voluntary redistribution of resources, with neither side having an incentive to fight.

War can occur, however, in a situation of asymmetric information, where one country is informed of all the parameters of the problem, and the other is not informed about the parameter characterizing the first country's aversion to war. In such a situation, war can occur if "the uninformed country adopts a separating equilibrium strategy, in which it precommits itself to a positive probability of war in order to prevent bluffing by the informed country. However, there would be no conflict if the uninformed country finds it optimal to adopt a pooling equilibrium strategy, in which it does not attempt to prevent such bluffing." (1985, p. 944). It should be noted that this conclusion is not based on a historical or concrete analysis of destruction or violence. Neither the First World War nor the Second World War can be explained on the basis of asymmetrical information between belligerent countries. In fact, Brito and Intriligator try to show that incomplete information is a sufficient logical condition to justify the rational possibility of resorting to destruction or violence. This, however, does not imply that real wars are caused by a situation of asymmetric information.

Randomness of political events is another factor which has been raised to explain the genesis of collective violence. In Kauffmann's linear model (2007), short term and event interdependence matters. Given that rational people usually do not rebel, stochastic models show that instances of rebellion are largely random events (Lichbach, 1992; Blattman and Miguel, 2009). By the same token, the modelers could argue that rational people usually do not innovate (since they should know everything in advance, the ignorance as well as novelty have no room in their universe), as instances of innovation are largely random events. But, the fact that revolution (a social innovation), like any other type of innovation, is a "random" event, does not tell anything about its nature, its origin, and its internal logic or "rationality". Timur Kuran (1989) models the role of random events and social psychology in helping to determine the success of insurrections. He tries to support his theory using three historical examples, namely the French Revolution of 1789, 
the Russian Revolution of February 1917, and the Iranian Revolution of February 1979. Undoubtedly, socio-political instability is marked by unpredictability of random events. And incomplete information or even sheer ignorance regarding the outburst of revolution is something well known. But these rudimentary truths are not sufficient to provide an internal explanation for violence and destruction.

\subsubsection{Common property models}

There exist two different types of common property models. In the first type of models, agents adopt simple strategies. By simple strategies, I mean an optimal constant rate of appropriation of the common property (Tornell and Velasco, 1992; Lane and Tornell, 1995, 1996, 1999). In the second type of models, agents' decisions of whether to cooperate or appropriate depend on the level of wealth (Benhabib and Rustichini, 1996; Long and Sorger, 2004). This type of models is named "common property models with wealth-dependent appropriation" (Drazen, 2000, p. 507).

\section{Growth in common property models with constant rate of appropriation}

Lane and Tornell (1996) provide a growth model of common property with a constant rate of appropriation. The starting point of this model is that, on average, resource-rich countries do not grow quickly and do not have the highest incomes per capita. Two salient examples are Venezuela and Nigeria. In the former case, the terms of trade grew at an average annual rate of 13.7 percent over 1970 to 1990 due to sudden increases in oil revenues. However, Venezuela's output per capita declined by 28 percent during the same period. In the latter case, Nigeria enjoyed the oil windfall of the 1970s and early 1980s, whereas its GDP per capita over 1970 to 1990 showed a mediocre annual performance of 0.03 percent. The authors also cite the example of Trinidad and Tobago, an oil producer, that grew at only 1.2 percent annually over 1970 to 1990, and GDP per capita contracted at a rate of -2.75 percent per year over 1980 to 1990.

To explain this paradox, Lane and Tornell extend the neoclassical growth model by replacing the representative agent with multiple powerful groups. They define these groups as: "coalitions with power to extract transfers from the rest of society. Examples are provincial governments that extract transfers from the centre, strong unions and industrial conglomerates that seek protection, and patronage networks that obtain kickbacks from public works." (1996, p. 214). Thus, the appropriative activity of powerful groups is described as their power to extract common resources for their private consumption.

The "voracity effect" (Lane and Tornell, 1996, 1999) measures the amount of resources that is appropriated by these groups following an increase in the rate of return of common resources such as oil. Put differently, any increase in the oil revenue in Venezuela, Nigeria, or for Trinidad and Tobago where such powerful groups are dominant, provoke a voracity effect: the private consumption of these groups surpasses the amount of increase. The appropriative activity of powerful groups reduces growth rate due to the voracity effect. The model ignores the specific institutional matrix of society. Instead, it assumes that society is made up of powerful groups that can either cooperate or be in conflict. The conflict is related to rent-seeking or appropriative activity. 
Lane and Tornell $(1996,1999)$ assume a "one sector" growth model. In their earlier model (Lane and Tornell, 1995), they assumed a second sector that was secure from appropriation by others but offered a lower rate of return. Tornell and Velasco (1992) have also studied the effect of a second sector with a lower rate of return (an inferior technology, namely saving money in foreign bank deposits with lower rate of interest) in order to analyze the capital flow from poor to rich countries. They have showed that due to insecurity, economic agents in poor countries prefer to deposit their savings in rich countries where the rate of return is inferior compared to their own countries but is immune from appropriative activity. Lane and Tornell (1996) assume that powerful groups do not have access to an additional private accumulation. The production technology is linear with the marginal product of capital being equal to $F^{\prime}(K)=\alpha$. The aggregate output is linear in the aggregate capital stock $\mathrm{K}(\mathrm{t})$, and the change in the aggregate capital stock is simply the output minus the total sum of the private consumption of powerful groups at each point in time. Assuming $\mathrm{J}(>1)$ groups, we have

$$
\mathrm{K}^{0}(\mathrm{t})=\alpha \mathrm{K}(\mathrm{t})-\sum_{\mathrm{j}=1}^{\mathrm{n}} \mathrm{C}_{\mathrm{j}}(\mathrm{t})
$$

where $C_{j}(t)$ is the private consumption or appropriation of group $(j)$ at time $t$.

Agents' preferences are represented by CES functions. The objective function of each group is defined over an infinite horizon:

$$
\mathrm{U}^{\mathrm{j}}=\int_{\mathrm{t}=\mathrm{s}}^{\infty} \sigma / \sigma-1 \mathrm{C}_{\mathrm{j}}(\mathrm{s})^{\sigma-1 / \sigma} \mathrm{e}^{-\rho(s-\mathrm{t})} \mathrm{ds}
$$

where the elasticity of inter-temporal substitution is $\sigma>0$ and where $\rho<\alpha$. There is an upper bound $(\Gamma)$ on the rate of appropriation by each group. Hence

$$
0 \leq \mathrm{C}^{\mathrm{j}}(\mathrm{t}) \leq \Gamma^{\mathrm{K}} \mathrm{K}(\mathrm{t}), \text { where } 0 \leq[\alpha(1-\sigma)+\rho \sigma] /[\mathrm{J}-\sigma(\mathrm{J}-1)]<\dot{\Gamma}<\infty
$$

The output cannot be appropriated all at once. The value $[\alpha(1-\sigma)+\rho \sigma] /[\mathrm{J}-\sigma(\mathrm{J}-1)]$ is the appropriation rate in an interior equilibrium. Each group's strategy is to choose an optimal consumption stream $\mathrm{C}^{\mathrm{j}}(\mathrm{t})$ to maximize (2) subject to (3) and the strategies of the other players. Lane and Tornell consider Markov strategies, namely strategies that are restricted to be functions only of the pay off relevant state variables and are not allowed to be history dependent. Subsequently, they define the interior equilibrium as well as extreme equilibria of their model. In the interior equilibrium, the appropriation rates of all groups lie in the interior of the appropriation set.

In addition to this type of equilibrium, for some parameter values, there exist two extreme Markov perfect equilibria. Having examined the conditions of the stability of the interior equilibrium in the presence of multiple equilibria, Lane and Tornell study the "voracity effect". They define the "voracity effect" as follows: "a more than proportional increase in aggregate redistribution in response to an increase in the raw rate of return $(\alpha)$." (1996, p. 226). The question is then to identify conditions under which the existence of powerful groups leads to a perverse response to positive productivity or terms of trade shocks, in which redistribution increases and the growth rate falls. Their results can be summarized in the following proposition. "Proposition 2: (The Voracity Effect). A positive shock to productivity or to the terms of trade: i) Leads to a reduction in the growth rate if only if there exist multiple powerful groups that act 
non-cooperatively and $\sigma>\mathrm{n} / \mathrm{n}-1^{14}$; ii) Leads to an increase in the growth rate if groups have no power to extract transfers from the rest of society, or their behaviour is coordinated by a central planner." (1996, p. 227).

In other words, if the inter-temporal elasticity of substitution is sufficiently low, powerful groups will not appropriate excessively, and the "voracity effect" does not operate. Moreover, Lane and Tornell's model confirm Olson's result $(1982,1993)$ that if there exist only one long-lived powerful group or a few powerful groups that can coordinate and act cooperatively, then firstbest policies will be implemented, and the outcomes will be those of the representative agent model. The "voracity effect" holds when there are a few powerful groups that cannot act cooperatively and the inter-temporal elasticity of substitution is high enough, namely: $\sigma>\mathrm{J} / \mathrm{J}-1$.

The authors also construct a dummy variable dubbed as "Power". Applying this "Power" dummy variable, they dichotomize countries into a group that has slow growth and responds negatively to terms of trade shocks and a group with relatively higher growth which responds positively to terms of trade shocks. Venezuela, Nigeria, Trinidad and Tobago are part of the first group with a high rate of the "voracity effect".

The "voracity effect" measures the extent of rent-seeking or appropriative activity of organized powerful groups. The "powerful groups" are not limited to ruling classes, military elites, or other dominant groups. They include workers' unions, or other types of employees' pressure groups. If in a country there exist strong workers' and employers' unions that cannot act cooperatively, the "voracity effect" will operate, whereas in the presence of a powerful dictatorial regime (a unique long-lived powerful group banning trade unions) the "voracity effect" will not operate. But it is a well known fact that social conflicts usually precede social compromises, and hence workers' and employers' unions cannot achieve an acceptable compromise without testing their relative strength.

It means that a period of social conflict is a necessary historical requisite to achieve a cooperative behaviour by both sides of the employment relationship. Lane and Tornell's model does not capture the social and historical advantages of a democratic regime with "two-sided collective action" (according to Commons's terminology, 1970) compared to a centralized dictatorial regime. The reason is that the "voracity effect" can operate in such a democratic regime with non-cooperative "powerful groups", whereas in a centralized dictatorial regime, the "voracity effect" cannot operate, since there is no right for trade unions. This result is due to three underlying assumptions in Lane and Tornell's model.

First, they ignore the specific institutional matrix of the society, and focus only on the role of "powerful groups". Thus the role of "rules" in society, the type of state and the level of development of the civil society are ignored.

Second, in defining the strategies of agents, they consider Markov strategies which are not history dependent. Hence, they cannot distinguish between different conflictual processes according to their historical role in developing or hindering a democratic social compromise. This lack of distinction between the different types of conflictual processes undermines the clarity of

\footnotetext{
${ }^{14}$ Using the variables adopted by me, this condition can be expressed as follows : $\sigma>\mathrm{J} / \mathrm{J}-1$
} 
the "voracity effect". The "voracity effect" includes both the appropriative power of pressure groups and the necessary social conflict between organized workers' and employers' unions in order to achieve a "two-sided collective action".

Third, the competitive market economy with atomized agents (or with a centralized planner or a Walrasian crieur de prix) is supposed to be the ideal economy where the "voracity effect" is null. Hence, any social conflicts as well as any workers' or employers' unions are regarded as a deviation from Pareto-optimality. This doctrinal vision of the market economy disregards the close relationship between social conflicts, growth and wealth distribution.

\section{Growth in common property models with wealth-dependent appropriation}

Benhabib and Rustichini (1996), like Lane and Tornell (1996, 1999), develop a common property model. However in their model, the decision of whether to cooperate or appropriate may depend on the level of wealth. The starting point of this model is the observation that contrary to the prediction of Neoclassical growth theory, poor countries do not grow at faster rates than rich countries. In fact, poor countries have usually invested at lower rates, experienced more intense social conflict and political instability, and consequently have not grown faster than rich countries. Put differently, there is a robust negative correlation between investment and various measures of political instability, and that investment-reducing political instability appears to depend on the level of income. The representative agent is replaced by "organized social groups" that can capture, or attempt to capture, "a larger share of the output either by means of direct appropriation or by manipulating the political system to implement favourable transfers, regulations, and other redistributive policies." (1996, p. 126). Such appropriative activity can provoke significant disincentives to accumulate, and can be stronger at lower than higher levels of wealth, so that poorer countries may grow more slowly or even stagnate at lower levels of growth (which Benhabib and Rustichini, 1996, p. 126 call "growth trap").

To capture this relationship between growth and wealth, the authors use a simple dynamic game theoretical model. Organized social groups can follow an appropriative strategy, but this type of strategy eventually generates retaliation in the future. In other words, defection by one player from cooperative behaviour provokes other players to adopt non-cooperative behaviour in the future, resulting in a complete exhaustion of the capital stock. Whether high or low levels of wealth depress investment and growth rates critically depend on the curvatures of technology and preferences. Both cases are possible. Lower wealth may lead to lower growth and sometimes, to a "growth trap". This case is more likely when there are sufficiently high diminishing returns in utility, since when wealth and consumption are high, the utility value of appropriating more consumption in the present is less attractive, than the cost of retaliation in the future.

With the same token, the opposite may also be true at lower levels of wealth, when consumption is low and marginal utility is high. The utility value of appropriating more consumption in the present outweighs the cost of future retaliation. Conversely, if the marginal utility of consumption does not diminish significantly as consumption rises, compared to the decreasing marginal productivity of capital, the opposite will be true. At low levels, capital is too valuable to risk the retaliation. As capital becomes more abundant, fully cooperative behaviour cannot be guaranteed, and inefficiency will reappear. Thus Benhabib and Rustichini (1996) share with Olson (1982) the 
idea that in a mature rich economy (like England), there may exist inefficiencies due to organized groups exerting redistributive pressures.

Unlike the Lane and Tornell (1996) model, in which there is an exogenous upper bound on the rate of appropriation ${ }^{15}$, the only limit on appropriation is the total level of resources. Since there is no exogenously upper bound on appropriation, total consumption of the two players may exceed available output, so an allocation rule must be specified. This rule has to relate the consumption of the two players $\left(c_{1}\right.$ and $\left.c_{2}\right)$ to the amount of output allocated to them $(f(k))$. For instance, for the first player, the authors specify the following rule:

$$
\mathrm{A}_{1}\left(c_{1}, c_{2}, \mathrm{k}\right)= \begin{cases}c_{1} & \text { if } c_{1+} c_{2} \leq f(k) \text { or } c_{1} \leq f(k) / 2 \\ f(k)-c_{2} & \text { if } c_{1}+c_{2} \geq f(k) \text { and } c_{1} \geq f(k) / 2 \geq c_{2} \\ f(k) / 2 & \text { if } c_{1, c_{2} \geq f(k) / 2}\end{cases}
$$

and a similar allocation rule for $\mathrm{A}_{2}($.$) for the second player. Then, one possibility is that each$ player tries to appropriate as much as s/he can. In this case, all output is consumed in one period. More formally, Benhabib and Rustichini consider the pair of "fast consumption strategies" (1996, p. 128) $\hat{c}_{1}(\mathrm{k})=\hat{\mathrm{c}}_{2}(\mathrm{k})=\mathrm{f}(\mathrm{k})$. This will be a subgame-perfect equilibrium, and the value to player (j) of this equilibrium is

$$
\mathrm{V}_{\mathrm{j}}^{\mathrm{D}}\left(\mathrm{k}_{0}\right)=\sum_{\mathrm{t}=0}^{\infty} \beta^{\mathrm{t}} \mathrm{u}\left(\mathrm{A}_{\mathrm{j}}\left[\hat{\mathrm{c}}_{1}\left(\mathrm{k}_{\mathrm{t}}\right), \hat{\mathrm{c}}_{2}\left(\mathrm{k}_{2}\right), \mathrm{k}_{2}\right]\right)=\mathrm{u}\left[\mathrm{f}\left(\mathrm{k}_{0} / 2\right)\right]
$$

Where $\beta$ is the discount factor and $u($.$) is the instantaneous utility function for both players.$

Fast consumption strategies are important, since they are the punishment after a defection from a cooperative equilibrium. In other words, if one group adopts a non-cooperative strategy, others will also stop playing cooperatively and try to appropriate as much as they can. Hence they will be induced to adopt a fast consumption strategy. Equation (2) defines the threat level in this trigger equilibrium. Thus, any equilibrium must respect an individual rationality constraint of the following form

$$
\sum_{\mathrm{t}=0}^{\infty} \beta^{\mathrm{t}} \mathrm{u}\left(\mathrm{c}_{\mathrm{j}}(\mathrm{t})\right) \geq \mathrm{V}_{\mathrm{j}}^{\mathrm{D}}\left(\mathrm{k}_{0}\right),
$$

where $c_{j}(t)$ is the level of consumption in the equilibrium. Benhabib and Rustichini consider two other equilibrium concepts, namely a first-best equilibrium and a second-best equilibrium in order to derive possible growth paths and from that, the possibilities for welfare-maximizing growth (1996, pp. 129-133).

They subsequently discuss wealth-dependent strategies, and show that the possibility of enforcing a first-best equilibrium may depend on the level of wealth. One possibility, consistent with "poverty traps" is that first-best behaviour, and hence first-best growth rates are sustainable from high levels of wealth, but not from low levels, because of the incentive compatibility constraints. Their intuition is that when stocks of capital are low, it is not possible to increase the

\footnotetext{
${ }^{15}$ Lane and Tornell (1996) also consider a lower bound on appropriation, but as Drazen (2000, p. 503) rightly argues, this lower bound plays a less critical conceptual role in their analysis and can be ignored.
} 
consumption enough to avoid defection. The alternative wealth-dependent case is where cooperative behaviour is sustainable from low levels of $(\mathrm{k})$, but not from high levels. Benhabib and Rustichini call this possibility "an 'Olson' case" (1996, pp. 137-139). This case alludes to "mature" societies (societies with high levels of income, like England in Olson's 1982 example) which suffer from a low level of growth rate due to the appropriative activity of powerful interest groups.

By focusing on second-best sub-game perfect equilibria, the authors' contribution is in illustrating that growth rates can indeed be wealth dependent. Poor countries may indeed accumulate at lower rates because even for the best sustainable equilibria, the incentives for appropriation can be much stronger at low levels of wealth than at high levels, and thus the momentary advantages of defection can be overcome only with high consumption and low level investment rates. The model elegantly explains the relationship between appropriative strategies and different levels of wealth. However, the authors, like Lane and Tornell, ignore the specific institutional matrix of society, and focus only on the role of "organized social groups". Thus the role of "rules" in society, the type of state and the level of development of the civil society are ignored. In Benhabib and Rustichini (1996), "organized social groups" are defined in the same way as "powerful groups" in Lane and Tornell (1996, 1999). Labour unions as well as employers' unions are considered to be part of "organized social groups". The model assumes that "suppression of interest groups under authoritarian regimes may have increased the cost of defection and appropriation, making way for first-best growth." (1996, p. 141). Two examples are given: Korea and Chile.

Undoubtedly, Pinochet's coup d'état and the overthrow of Allende's government led to the suppression of all kinds of non governmental associations as well as independent labour unions. In this sense, Pinochet's authoritarian regime suppressed some "interest groups" and according to the authors, in doing so, he contributed to Chilean economic growth. In fact, the authors' fundamental assumption is that poorer countries are more prone to political instability. Therefore, an authoritarian regime that provides political stability may be beneficial to economic growth in poorer countries. But once the country becomes richer and the increased rate of growth becomes sustainable, then the authoritarian government will no longer be necessary. Applying this recipe to Korea and Chile, the authors contend: "Later, once the original switching threshold was crossed, first-best growth may have become self-sustaining and the authoritarian regimes toppled, as they no longer were necessary to sustain growth. A more recent example, following the path of Chile, may be Peru." (1996, p. 141, underlined by me). Benhabib and Rustichini (1996) show this "switching threshold" in their Figure 2 (p. 136), and argue that only after the threshold wealth level of $\left(\mathrm{k}_{1}\right)$ has been reached does growth resume its higher first-best level. There is an implicit political pattern in their model for "poorer countries": first, economic growth under an authoritarian regime; then political democracy. Hence, we first need a Pinochet to establish a "free" market economy, then we can have our "free" parliamentary democracy"

\footnotetext{
16 The same type of argument has been advanced to justify the use of « an iron hand» in China during the Tiananmen's events in spring 1989. According to this kind of political philosophy, the new Chinese market economy, like the Chilean economy, apparently needs an authoritarian regime (Pinochet's type of government) in the first place, then there will come a time when it can have its democratic regime.
} 
But, what guarantees that once the threshold wealth level of $\left(\mathrm{k}_{1}\right)$ has been reached, political instability will not be unleashed? In fact, there are many examples that show political instability following a certain level of growth in developing countries. The Iranian February revolution in 1979 followed a long period of growth rate since the agrarian reform in 1963 and six years after the first petrol shock in 1973. In other words, there is no linear relationship between political instability and growth. As Huntington (1968) highlights when poor or developing countries experience a "period of takeoff' and rapid growth, social and political unrest may actually increase. Not only new demands are generated, and the process of urbanization accelerates, but also the need to change archaic institutions and to build new ones to cope with social and economic transformation become pressing.

Developed countries, unlike developing ones, already have some basic institutions to deal with social and economic transformations, although even in these countries, socio-political instability is not excluded in certain situations such as May 1968 in France ${ }^{17}$ or the United States during the Vietnam War. In developing countries, this institutional change is frequently accompanied by social turmoil and political revolutions. Huntington defines "revolution" in such countries as part of the "modernization" process: "Revolution is...an aspect of modernization...(I)t is most likely to occur in societies which have experienced some social and economic development and where the process of political modernization and political development have lagged behind the process of social and economic change." (1968, p. 265).

While I agree with Huntington's analysis regarding revolution as an aspect of modernization in developing countries, it seems to me that he does not sufficiently take into account the importance of the international system. As Theda Skocpol (1979) rightly pinpoints not only class competition and conflict, but also nation-state rivalry, competition, and war play a crucial role in the genesis of revolutions. The machinations of foreign states have played a decisive part in the history of the world's poor countries, most of which are small and weak. Moreover, it was colonialism that set the stage for many contemporary revolutions. Given the course of World War II, it is not surprising that in its aftermath there was social upheaval in Korea, China, Vietnam, and Burma. And if Churchill had remained in power, India too, would likely have been torn by even more political turmoil, with democracy being an unlikely outcome. In Africa, the reluctance of the French to leave Algeria contributed to that country's radicalization, a lesson ignored by the Portuguese in Guinea-Bissau, Mozambique, and Angola. In these cases and others, Skocpol perspicaciously intimates that the roots of revolutions should be sought in the "specific interrelations of class and state structures and the complex interplay over time of domestic and international developments." (1979, p. xiii).

Contrary to more abstract and axiomatic approaches to revolution and political instability, the case-study method of Skocpol has the particular merit of insisting on specific historical circumstances. In this perspective, the long-term outcome of revolution is not just a progression to a more "efficient" economy and the political ascension of a formerly subordinate class. As Collburn asserts, as a result of revolution, "the state itself comes to have growing power and autonomy." (1994, p. 12). The recognition of the autonomy of politics with regard to economics

\footnotetext{
${ }^{17}$ It is noteworthy that the political events in May 1968 in France also occurred at the end of a protracted period of economic growth following the Second World War, with a 5.5 percent average annual rate of growth. These "thirty glorious years" were an unprecedented enduring growth for all developed countries.
} 
implies that there is no linear relationship between economic growth and political instability. Regrettably, the model of Benhabib and Rustichini (1996), like all other models inspired by Public Choice approach, is based on economic determinism. This means that all institutional and political change is directly associated with economic change and the autonomy of political and institutional evolution is denied. In fact, "economic imperialism" involves a linear relationship between political instability and economic growth: poor countries with low rates of growth are prone to instability, whereas rich countries with high rates of growth are marked by political stability. However, such a linear relationship cannot capture the independent role of destructive power with regard to economic or creative power.

\section{Conclusion}

The main finding of this paper is that both strands of recent economic literature, namely the Strategic Conflict theory and Public Choice have not yet come to grips with social conflicts. The application of standard microeconomic assumptions to the field of "social conflicts" and the extension of Coasian theorem to coercive power have resulted in reducing conflicts either to "rational conflicts"-a threat of conflict without any real clash-or "real self-interested private conflicts". In other words, economic theory has considered social protesters either as (potential or actual) looters or as lunatics (irrational), but never as a group of people struggling for a common cause.

Generally speaking, the two theories provide no internal explanation for real destruction and violence. In rare cases where an explanation of "violence and real destruction" is suggested, it is reduced to asymmetric information or random events. The "unpredictable" character of social destructive behaviour is a rudimentary truth, and a reference to "randomness" of political events is very far from any serious analysis of the phenomenon. Asymmetric information is perhaps a logical explanation for the emergence of violence and real destruction, but it cannot be a great help to grasp the nature of major wars such as the two World Wars. In fact, conflict theory and political instability models have not overcome the limits of the mainstream economics to reconcile "social conflicts" with the ubiquitous market model and the assumption of privately interested individual agents.

Moreover, these models do not distinguish between different types of collective rebellion, criminal activity and warlike activities. They are all regarded as "predatory", "appropriative", or "rent-seeking" activities. This is due to the fact that all these models ignore the institutional setup of the societies, and the strategies of the agents are supposed to be rational but not history dependent.

Finally, these models are based upon economic determinism, namely the denial of autonomy for the political sphere with regard to economic activity.

\section{Bibliography}


Alesina A. and Perotti R. (1994), "The Political Economy of Growth: A Critical Survey of the Recent Literature," World Bank Economic Review, vol. 8, pp. 351-371.

Anderson J. and Marcouiller D. (2002), «Insecurity and the Pattern of Trade : An Empirical Investigation », The Review of Economics and Statistics, Vol. 84, No. 2, pp. 342-352.

Anderson J. and Marcouiller D. (2005), «Anarchy and Autarky: Endogenous Predation as a Barrier to Trade », International Economic Review, Vol. 46, No. 1, pp. 189-231.

Anderton C., Anderton R., and Carter J. (1999), "Economic Activity in the Shadow of Conflict", Economic Inquiry, Vol. 37, No. 1, pp. 166-179.

Arendt H. (1970), On Violence, San Diego, N.Y., London, A harvest Book Harcourt Brace and Company.

Aristotle (1979), Politics, translated with an introduction by T.A. Sinclair, Penguin Books.

Avery C., and Zemsky P.B. (1994), "Money burning and multiple equilibria in bargaining," Games and Economic Behavior, vol. 7, pp. 145-68.

Becker G. S. (1968), “Crime and Punishment: An Economic Approach”, Journal of Political Economy, Vol. 76, No. 2, pp. 169-217.

Becker G. S. (1983), “A Theory of Competition among Pressure Groups for Political Influence,” Quarterly Journal of Economics, vol. 98, pp. 371-400.

Benhabib J. and Rustichini A. (1996), "Social Conflict and Growth," Journal of Economic Growth, vol. 1, pp. 125142.

Blattman C. and Miguel E. (2009), “Civil War”, NBER Working Paper, No. w14801, March.

Boulding K. E. (1962), Conflict and Defense: A General Theory, New York, Harper and Brothers.

Bowles S. and Gintis H. (1988), "Contested Exchange: Political Economy and Modern Economic Theory", American Economic Review, Vol. 78, No. 2, May, pp. 145-150.

Bowles S. and Gintis H. (1990), "Contested Exchange: New Microfoundations for the Political Economy of Capitalism”, Politics and Society, Vol. 18, No. 2, June, pp. 165-222.

Brito D. L., and Intriligator M. D. (1985), "Conflict, War, and Redistribution," American Political Science Review, vol. 79, December, pp. 943-57.

Buchanan J. (1975), The Limits of Liberty: Between Anarchy and Leviathan, Chicago, The University of Chicago Press.

Busch L.A, Shi S., and Wen Q. (1998), "Bargaining with surplus destruction,” Canadian Journal of Economics, vol. 38 , no. 4 , October.

Bush W. (1972), "Individual Welfare in Anarchy”, in Tullock G. (ed.), 1972, pp. 5-18; see also, Stringham E. (ed.) [2005], Chapter 2, pp. 10-23.

Bush W. and Mayer L. (1974), "Some Implications of Anarchy for the Distribution of Property", Journal of Economic Theory, Vol. 8, pp. 401-412.

Coase R. (1960), “The Problem of Social Cost”, The Journal of Law and Economics, Volume III, October, pp. 1-44.

Colburn F. D. (1994), The Vogue of Revolution in Poor Countries, Princeton, N.J., Princeton University Press. 
Collier P. and Hoeffler A. (2007), "Civil War", in Sandler T. and Hartley K. (eds.), Handbook of Defense Economics, Volume 2, Defense in a Globalized World, Amsterdam, North-Holland, Chapter 23, pp. 711-739.

Collier P., Hoeffler A., and Rohner D. (2009), "Beyond greed and grievance: feasibility and civil war", Oxford Economic Papers, Vol. 61, pp. 1-27.

Commons J. R. (1970), The Economics of Collective Action, Madison, WI, University of Wisconsin Press.

Coser L. (1956), The Functions of Social Conflict, New York, The Free Press.

Dasgupta P. and Maskin E.S. (1989), Bargaining and destructive power, Discussion Paper 1432, Harvard Institute of Economic Research, Harvard University.

Drazen A. (2000), Political Economy in Macroeconomics, Princeton, N.J., Princeton University Press.

Findlay R. (1996), "Toward a model of territorial expansion and the limits of empire," in Garfinkel M. and Skaperdas (eds.), The Political Economy of Conflict and Appropriation, Cambridge University Press, Cambridge, chapter 3 .

Galtung J. (1965), "Institutionalized Conflict Resolution: A Theoretical Paradigm,” Journal of Peace Research, no. 4, pp. 348-97.

Garfinkel M. and Skaperdas S. (1996), "Introduction” in Garfinkel M. and Skaperdas S. (eds.), The Political Economy of Conflict and Appropriation, Cambridge University Press, Cambridge, pp. 1-14.

Garfinkel M. and Syropoulos C. (1996), "Competitive trade with conflict," in Garfinkel M. and Skaperdas (eds.), The Political Economy of Conflict and Appropriation, Cambridge University Press, Cambridge, chapter 5.

Garfinkel M. and Skaperdas S. (2007), "Economics of Conflict: An Overview”, in Sandler T. and Hartley K. (eds.), Handbook of Defense Economics, Volume 2, Defense in a Globalized World, Amsterdam, North-Holland, Chapter 22, pp. 649-709.

Goodwin R. (1968), The New Yorker, February 17.

Grossman H. (1991), "A General Equilibrium Model of Insurrections," American Economic Review, vol. 81, no. 4, September, pp. 912-21.

Grossman H., and Kim M. (1995), "Swords or Plowshares? A Theory of the Security of Claims to Property," Journal of Political Economy, vol. 103, pp. 1275-88.

Grossman H., and Kim M. (1996a), "Predation and Production", in Garfinkel M. and Skaperdas (eds.), The Political Economy of Conflict and Appropriation, Cambridge University Press, Cambridge.

Grossman H., and Kim M. (1996b), "Predation and Accumulation," Journal of Economic Growth, vol. 1, pp. 333-51.

Gupta D. (1990), The Economics of Political Violence, The Effects of Political Instability on Economic Growth, New York, Praeger.

Gurr T.R. (1970), Why Men Rebel, Princeton, Princeton University Press.

Haavelmo T. (1954), A Study in the Theory of Economic Evolution, Amsterdam, North-Holland. 
Habib-Deloncle L. (1998), “Les risques politiques,” in François Ewald, Jean-Hervé Lorenzi (eds.), Encyclopédie de l'Assurance, Paris, Economica, pp. 1213-1229.

Hibbs D. (1973), Mass Political Violence: A Cross-Sectional Analysis, New York, Wiley and Sons.

Hirschman A. O. (1970), Exit, Voice, and Loyalty, Cambridge Mass., Cambridge University Press.

Hirschman A. O. (1974), ““Exit, voice, and loyalty”: Further reflections and a survey of recent contributions”, Social Science Information, vol. 13, no. 1, February, pp. 7-26.

Hirschman A. O. (1981), Essays in Trespassing, Economics to Politics and Beyond, N.Y., Cambridge University Press.

Hirschman A. O. (1982), Shifting Involvements, Private Interest and Public Action, Princeton, New Jersey, Princeton University Press.

Hirshleifer J. (1987), Economic Behavior in Adversity, Chicago, University of Chicago Press.

Hirshleifer J. (1991a), “The Technology of Conflict as an Economic Activity,” American Economic Review, vol. 81, no. 2, May, pp. 130-134.

Hirshleifer J. (1991b), “The Paradox of Power,” Economics and Politics, vol. 3, November, pp. 177-200.

Hirshleifer J. (1995), “Anarchy and its breakdown,” Journal of Political Economy, vol. 103, February, pp. 25-52; reprinted in Garfinkel M. and Skaperdas (eds.), 1996, chapter 2.

Hirshleifer J. (2001), The Dark Side of the Force, Economic Foundations of Conflict Theory, Cambridge, Cambridge University Press.

Hobsbawm E. (1963), Primitive Rebels, Studies in Archaic Forms of Social Movement in the 19th and 20th Centuries, Manchester, University of Manchester Press.

Hobsbawm E. (1962), The Age of Revolution 1789-1848, London, Weidenfield and Nicolson.

Holden S. (1994), "Bargaining and commitment in a permanent relationship," Games and Economic Behavior, vol. 7, pp. 169-176.

Huntington S. P. (1968), Political Order in Changing Societies, New Haven, Conn, Yale University Press.

Janos A. (1964), The Seizure of Power: A Study of Force and Popular Consent, Research Monograph No. 16, Princeton, Center of International Studies, Princeton University.

Jodice D. and Taylor D. (1988), World Handbook of Social and Political Indicators, New Haven, CT, Yale University Press.

Kauffmann M. (2007), "Short Term and Event Interdependence Matter: A Political Economy Continuous Model of Civil War", Peace Economics, Peace Science and Public Policy, Vol. 13, No. 1.

Kennedy P. (1989), The Rise and Fall of the Great Powers: Economic Change and Military Conflict from 1500 to 2000, New York, Vintage Books.

Knack S. and Keefer P. (1995), "Institutions and Economic Performance: Cross-Country Tests Using Alternative Institutional Measures," Economics and Politics, vol. 7, pp. 207-27.

Kuran T. (1989), "Sparks and Prairie Fires: A Theory of Unanticipated Political Revolution,” Public Choice, vol. 61, April, pp. 61-74. 
Lanchester F. W. [1916] 1956, Aircraft in Warfare: The Dawn of the Fourth Arm, London, Constable; Extract in Newman J.R. (ed.), The World of Mathematics, volume 4, New York, Simon and Schuster, pp. 2138-57.

Lane P. and Tornell A. (1996), "Power, Growth, and the Voracity Effect," Journal of Economic Growth, vol. 1, pp. 213-41.

Lane P. and Tornell A. (1999), “The Voracity Effect”, American Economic Review, Vol. 89, pp. 22-46.

Lazear E. (2000), Economic Imperialism, Quarterly Journal of Economics, Vol. 115, No. 1, pp. 99-146.

Lerner A. (1972), “The Economics and Politics of Consumer Sovereignty”, The American Economic Review, Vol. 62 , No. 1/2, March, pp. 258-266.

Lichbach M. I. (1992), "Nobody cites nobody else: mathematical models of domestic political conflict," Defence Economics, vol. 3, no. 4, pp. 341-357.

Long N. And Sorger G., 2004, "Insecure Property Rights and Growth: The Roles of Appropriation Costs, Wealth Effects, and Heterogeneity", CESIFO Working Paper, No. 1253, August, www.ssrn.com

Macculloch R. (2005), "Income Inequality and the Taste for Revolution”, Journal of Law and Economics, vol. XLVIII, April, pp. 93-123.

Manzini P. (1997), "Strategic bargaining with destructive power: the role of commitment," Economics Letters, vol. 54 , pp. 15-22.

Manzini P. (1999), “Strategic bargaining with destructive power,” Economics Letters, vol. 65, pp. 315-322.

Mauro P. (1995), “Corruption and Growth,” Quarterly Journal of Economics, vol. 110, pp. 681-712.

McGuire M. and Olson M. (1996), “The Economics of Autocracy and Majority Rule", Journal of Economic Literature, Vol. XXXIV, No. 1, pp. 72-96.

Muthoo A. (1992), “Revocable commitment and sequential bargaining,” Economic Journal, vol. 102, pp. 378-387.

North D. (1977), "Markets and Other Allocation Systems in History: The Challenge of Karl Polanyi," Journal of European Economic History, Vol. 6, pp. 703-716.

Olson M. [1965] 1980, The Logic of Collective Action, Public Goods and the Theory of Groups, Cambridge Mass., London, Harvard University Press.

Olson M. (1982), The Rise and Decline of Nations: Economic Growth, Stagflation, and Social Rigidities, New Haven, Yale University Press.

Olson M. (1993), “Dictatorship, Democracy, and Development," American Political Science Review, vol. 87, pp. 567-576.

Pareto V. [1927] 1971, Manuel of Political Economy, Translated by Ann S. Schwier, New York, A.M. Kelly.

Perotti R. (1996), "Income Distribution, Democracy, and Growth: What the Data Say," Journal of Economic Growth, vol. 1, pp. 149-87.

Plekhanov G. [1894] 1974, “The development of the monist view of history," Selected Philosophical Works, vol. I, Moscow, Progress Publishers, pp. 480-737. 
Plekhanov G. [1897] 1976, "The Materialist Understanding of History," Selected Philosophical Works, vol. II, Moscow, Progress Publishers, pp. 596-627.

Popkin S. L. (1988), "Political Entrepreneurs and Peasant Movements in Vietnam," in Michael Taylor (ed.), Rationality and Revolution, New York, Cambridge University Press, pp. 9-62.

Rodrik D. (1997), Where Did All the Growth Go? External Shock, Social Conflict and Growth Collapses, Working Paper 6350, Harvard University.

Roemer J. E. (1985), “Rationalizing Revolutionary Ideology,” Econometrica, vol. 53, January, pp. 85-108.

Roemer J. E. (1988), "Rationalizing Revolutionary Ideology: A Tale of Lenin and the Tsar,” in Michael Taylor (ed.), Rationality and Revolution, New York, Cambridge University Press, pp. 229-44.

Sandler T. and Hartley K. (1995), The Economics of Defense, Cambridge, Cambridge University Press.

Schelling T. (1963), The Strategy of Conflict, N.Y., A Galaxy Book, Oxford University Press.

Schelling T. (1966), Arms and influence, New Haven, Yale University Press.

Schmidt C. (1993), “L’homo bellicus et la coordination économique, » Revue économique, vol. 46, no. 3, mai, pp. 529-550.

Sen A. (1983), “Cooperative Conflicts: Technology and the Position of Women”, mimeo, Oxford.

Skaperdas S. (1992), "Cooperation, Conflict, and Power in the Absence of Property Rights," American Economic Review, vol. 82, September, pp. 720-39.

Skaperdas S. and Syropoulos C. (1996), "Competitive Trade with Conflict”, in Garfinkel M. and Skaperdas S. (eds.), The Political Economy of Conflict and Appropriation, Cambridge, Cambridge University Press.

Skaperdas S. and Syropoulos C. (2002), "Insecure Property and the Efficiency of Exchange", The Economic Journal, Vol. 112, January, pp. 133-146.

Skocpol T. (1979), States and Social Revolutions, Cambridge, Cambridge University Press.

Skogh G. and Stuart C. (1982), "A Contractarian Theory of Property Rights and Crime," Scandinavan Journal of Economics, vol. 84, no. 1, pp. 27-40.

Stefanadis C. (2007), “Appropriation, Property Rights Institutions, and Openness to International Trade”, Working Paper, Department of Agricultural and Resource Economics, University of Arizona, December.

Stringham E. (ed.) (2005), Anarchy, State and Public Choice, Cheltenham and Northampton, Edward Elgar.

Stringham E. (ed.) (2007), Anarchy and the Law, The Political Economy of Choice, New Brunswick and London, Transaction Publishers.

Svensson L.E.O. (1998), "Investment, Property Rights, and Political Instability: Theory and Evidence," European Economic Review, vol. 42, pp. 1317-41.

Taylor M. (1988), "Rationality and Revolutionary Collective Action," in Michael Taylor (ed.), Rationality and Revolution, New York, Cambridge University Press, pp. 63-97.

Tong J. (1988), "Rational Outlaws: Rebels and Bandits in the Ming Dynasty," in Michael Taylor (ed.), Rationality and Revolution, New York, Cambridge University Press, pp. 99-128. 
Tornell A. and Velasco A. (1992), "The Tragedy of Commons and Economic Growth: Why does Capital Flow from Poor to Rich Countries?", Journal of Political Economy, vol. 100, pp. 1208-31.

Tornell A. (1997), "Economic Growth and Decline with Endogenous Property Rights," Journal of Economic Growth, vol. 2, pp. 219-50.

Tullock G. (1967), “The Welfare Costs of Tariffs, Monopolies, and Theft”, Western Economic Journal, June, pp. 224-32.

Tullock G. (1974), The Social Dilemma: The Economics of War and Revolution, Fairfax, VA: Center for the Study of Public Choice.

Tullock G. (1980), "Efficient Rent Seeking,” in Buchanan J.M., R.D. Tollison, and G. Tullock (eds.), Toward a Theory of the Rent-Seeking Society, College Station TX, Texas A\&M University Press.

Usher D. and Engineer M. (1987), “The Distribution of Income in a Despotic Society,” Public Choice, vol. 54, 1987, pp. 261-76.

Vahabi M. (2004), The Political Economy of Destructive Power, Cheltenham, Edward Elgar.

Vahabi M. (2009a), “An Introduction to Destructive Coordination”, American Journal of Economics and Sociology, Vol. 68, No. 2, April, pp. 353-386.

Vahabi M. (2009b), "Integrating Social Conflict into Economic Theory", Cambridge Journal of Economics, doi:10.1093/cje/bep 043, 14 July.

Vahabi M. (2010), "Economics of Destructive Power", in Braddon D. and Hartley K., Elgar Handbook on the Economics of Conflict, Cheltenham, Edward Elgar, Chapter 5, forthcoming.

Varoufakis Y. and Young D. (eds.), (1990), Conflicts in Economics, N.Y., Harvester, Wheatsheaf. 